\begin{abstract}
ipen
INSTITUTO DE PESQUISAS ENERGÉTICAS E NUCLEARES

AUTARQUIA ASSOCIADA À UNIVERSIDADE DE SÃO PAULO

EPIDEMIOLOGIA DA LEISHMANIOSE VISCERAL HUMANA EM

ARAGUAÍNA (TO) E O DIAGNÓSTICO SOROLÓGICO DA DOENÇA
\end{abstract}

ANETTE KELSEI PARTATA

Tese apresentada como parte dos requisitos para obtenção do Grau de Doutor em Ciências na Área de Tecnologia Nuclear - Aplicações.

Orientador:

Prof ${ }^{a}$. Dra. Nanci do Nascimento

São Paulo 
L̇ minha familia. 


\section{AGRADECIMENTOS}

Na realização deste, contei com a colaboração direta e indireta de várias pessoas, às quais agradeço profundamente. Algumas, ressalto a seguir:

Prof $^{a}$ Dra. Nanci do Nascimento, minha orientadora. Sua simplicidade, competência, clareza e objetividade me deram coragem para prosseguir;

Prof. Dr. Heitor Franco de Andrade Jr, do Laboratório de Protozoologia do IMT/FMUSP, por seus ensinamentos e sua disponibilidade no decorrer deste percurso;

Prof. Dr. Aparecido Osdimir Bertolin, por ter sonhado e idealizado todos os caminhos que iríamos seguir no curso;

Prof. Ms. André Machado Senna, pela paciência e sabedoria em conduzir todo esse processo;

Ms. Rosângela Magalhães Nunes, Diretora de Vigilância em Saúde, pela permissão ao acesso dos dados epidemiológicos;

Dra. Gláucia Leal, Dra. Farildes Lima Cutrim, Dra Iriatônia Lima e Marlene Rodrigues, do LSP de Araguaína, pelo acesso às amostras de soros;

Dra. Camila Carvalho, do Laboratório de Protozoologia do IMT/FMUSP, por sua presteza e cooperação. 
"Judo é do dPai, toda honra e toda glória $\dot{\mathcal{L}}$ Dele a vitória alcançada em minha vida...." 


\title{
EPIDEMIOLOGIA DA LEISHMANIOSE VISCERAL HUMANA EM ARAGUAÍNA (TO) E O DIAGNÓSTICO SOROLÓGICO DA DOENÇA
}

\author{
Anette Kelsei Partata
}

\section{RESUMO}

A Leishmaniose Visceral Humana (LVH) é uma protozoonose sistêmica grave que tem apresentado mudança no comportamento epidemiológico, com uma tendência crescente no Brasil. Na Região Norte, com a criação do Estado do Tocantins em 1989, houve aumento da incidência de LV em decorrência das modificações ecoepidemiológicas. Foi realizado um estudo descritivo de corte transversal para avaliar o quadro da LVH no município de Araguaína (TO) no período de janeiro de 2007 a agosto de 2010. Adicionalmente, foram realizados ensaios para comparar as abordagens diagnósticas sorológicas para o diagnóstico da doença. Na distribuição dos casos de LVH nos municípios do norte do estado do Tocantins, Araguaína representa 79,8\% no total dos casos no período de 2.007 a agosto de 2.010. Os resultados deste estudo revelaram que, nesse período, 769 casos foram confirmados, sendo que 98,7\% foram de casos novos. Houve um predomínio do sexo masculino de $57,8 \%$ e a faixa etária mais acometida foi a de 0 a 14 anos, com 71,3\% dos casos notificados. Na distribuição por zona de residência, foram notificados $98,5 \%$ dos casos na zona urbana, mostrando a urbanização da doença. Nos ensaios, foram utilizadas uma abordagem usual da rede do SUS: um ensaio de imunofluorescência indireta (IFI), um ELISA convencional, somados a um ELISA dissociativo. Os ensaios de ELISA apresentaram alta reprodutibilidade. Os pacientes positivos à IFI apresentaram uma frequência de $4 \%$ de falso-positivos quando testados em ambos os ELISA. Entre os pacientes suspeitos, houve uma alta frequência de positivos ao ELISA, maior no ELISA dissociativo do que no ELISA convencional. Na população assintomática, houve um achado de amostras positivas ao ELISA dissociativo. A presença de imunocomplexos em pacientes assintomáticos no início da doença ou sua presença em pacientes com resposta humoral menos intensa, como crianças, pode explicar estes achados de maior positividade no ELISA dissociativo. A confirmação destes resultados depende da pesquisa parasitológica em pacientes positivos ao ELISA dissociativo. Estes resultados mostram a importância de novas abordagens sorológicas no diagnóstico da LVH que viabilizariam uma triagem de paciente para diagnóstico parasitológico invasivo.

Palavras-chave: ELISA dissociativo, imunocomplexos, leishmaniose visceral humana. 


\title{
EPIDEMIOLOGY OF HUMAN VISCERAL LEISHMANIASIS IN ARAGUAÍNA (TO) AND SEROLOGICAL DIAGNOSIS OF THIS DISEASE
}

\author{
Anette Kelsei Partata
}

\begin{abstract}
Human visceral leishmaniasis (HVL) is a severe systemic protozoonosis that has presented changes at the epidemiological behavior, with a growing trend in Brazil. It has been conducted a cross sectional study to assess the context of HVL in the city of Araguaina (TO) from January 2007 to August 2010. Additionally, tests were conducted to compare the diagnostic approaches for the serological diagnosis. In the distribution of cases of HVL in the districts of northern state of Tocantins, Araguaina represents $79.8 \%$ of the total cases in the period from 2007 to August 2010. The results of this study revealed that in this period, 769 cases were confirmed, while $98.7 \%$ are new cases. There was a male predominance of $57.8 \%$ and the most affected age group was $0-14$ years, with $71.3 \%$ of reported cases. In the distribution by area of residence were reported $98.5 \%$ of cases in the urban area, showing the urbanization of the disease. In tests, we used the usual approaches network: an indirect immunofluorescence assay (IFA) and a conventional ELISA, plus a dissociative ELISA. ELISA assays showed high reproducibility. Positive patients with IFAT showed a frequency of $4 \%$ false-positive when tested in both ELISA. Among patients suspected there was a high frequency of positive to ELISA, the ELISA dissociative higher than in the conventional ELISA. In the asymptomatic population, there was a finding of positive samples by ELISA dissociative. The presence of immune complexes in asymptomatic patients early in the disease or its presence in patients with less intense humoral response, as children, these findings may explain the higher dissociative ELISA positive. Confirmation of these results depends on parasitologic research on dissociative ELISA-positive patients. These results show the importance of new approaches in the serological diagnosis LVH that would make a screening of patients for invasive diagnostic parasitology.
\end{abstract}

KEY WORDS: ELISA dissociative; Human visceral leishmaniasis; immune complexes 


\section{SUMÁRIO}

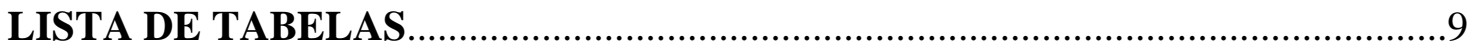

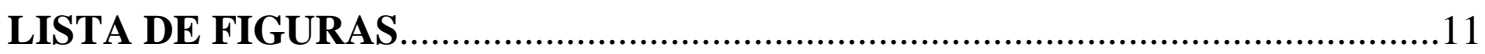

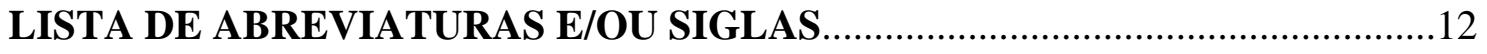

1 INTRODUÇÃ

2 OBJETIVOS

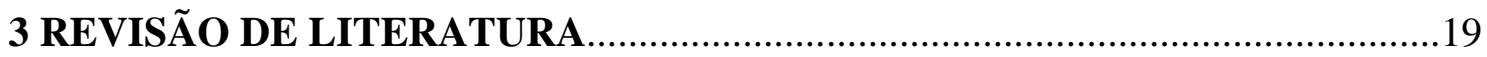

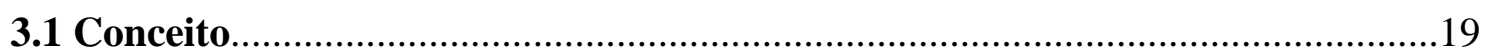

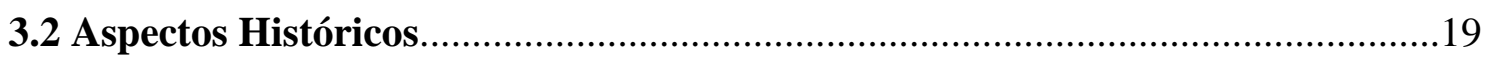

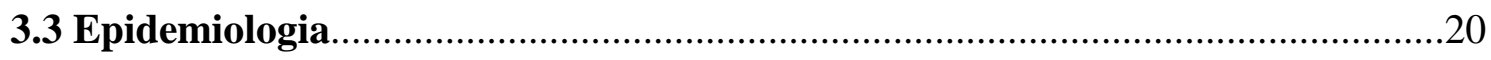

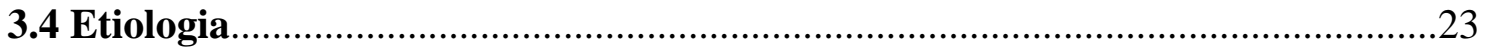

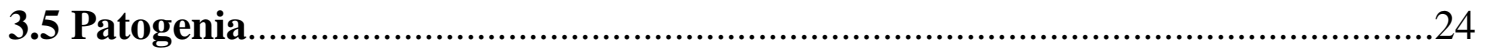

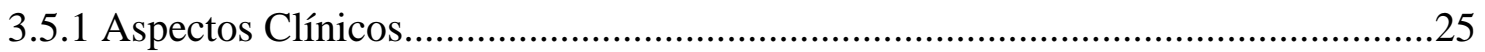

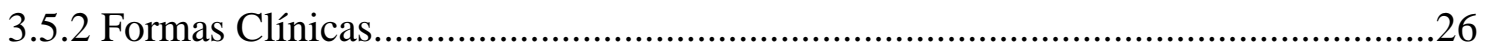

3.5.3 Co-infecção Leishmaniose Visceral Human versus HIV ....................................28

3.5.4 Leishmaníase Dérmica Pós-Calazar....................................................................28

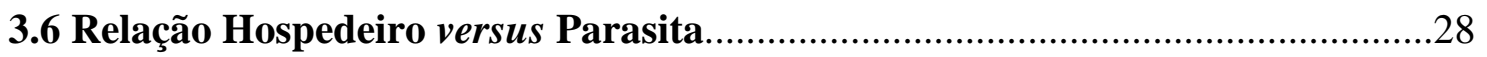

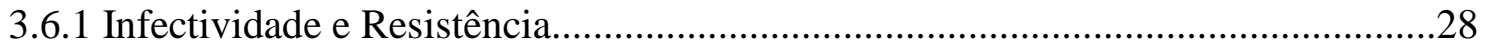

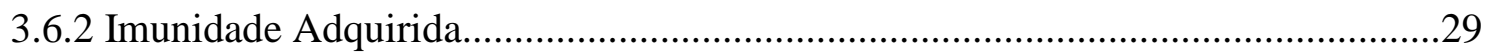

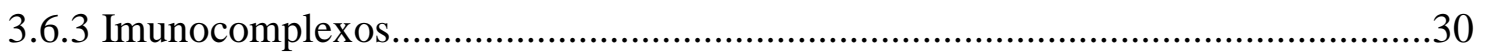

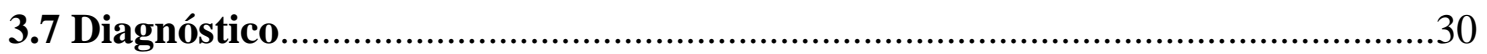

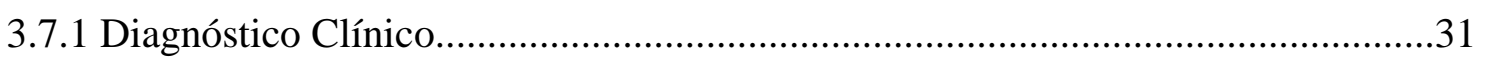

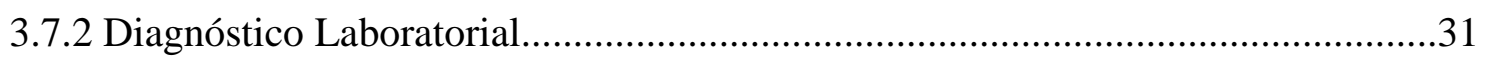

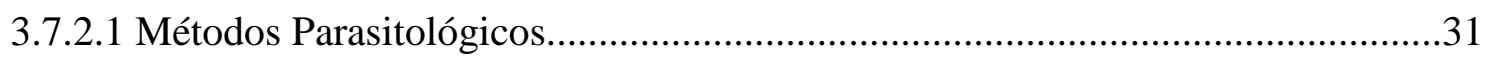

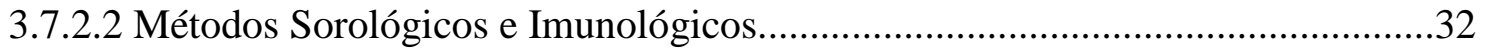

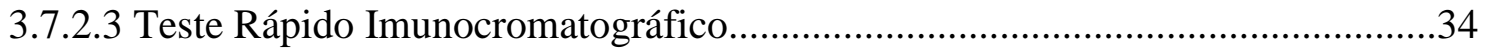

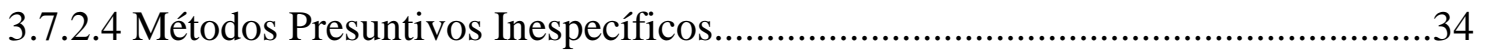

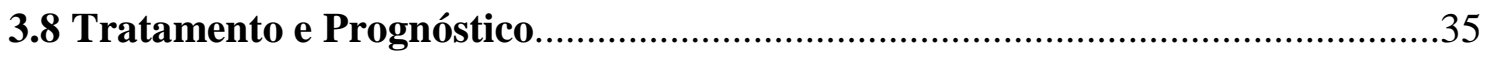

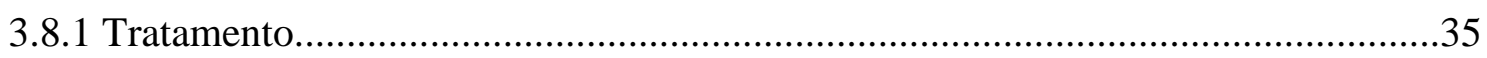

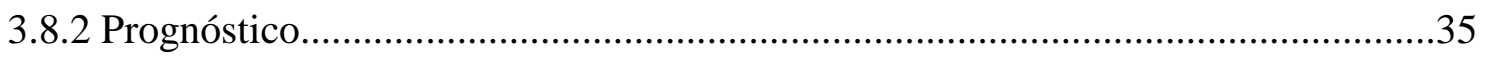




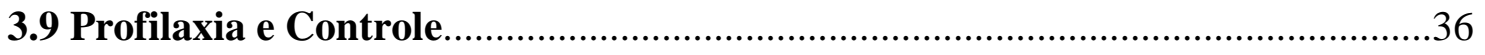

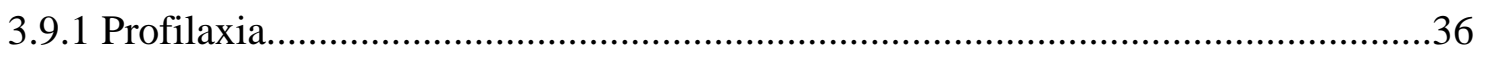

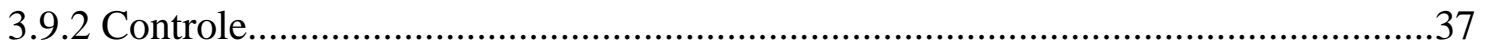

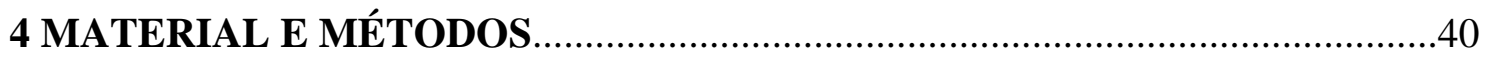

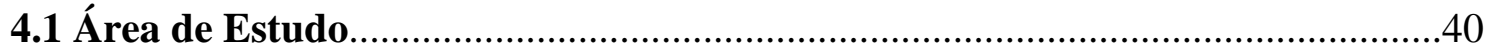

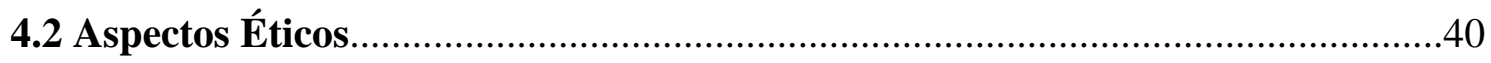

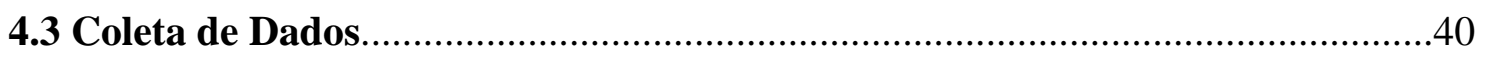

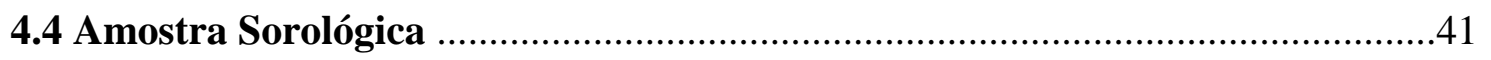

4.4.1 Amostra de pacientes portadores de LVH......................................................... 41

4.4.2 Amostra de pacientes suspeitos de LVH.................................................................

4.4.3 Amostra de pacientes não-suspeitos de LVH..........................................................41

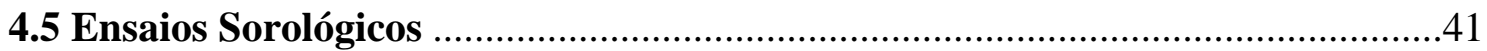

4.5.1 Reação de Imunofluorescência Indireta (RIFI)...................................................42

4.5.2 ELISA Convencional (ELISAH) e ELISA Dissociativo (ELISAD)......................42

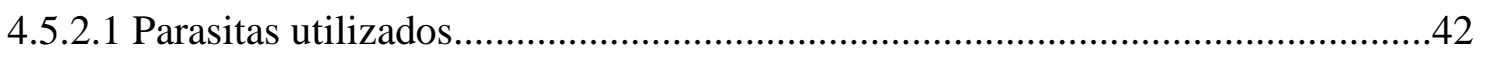

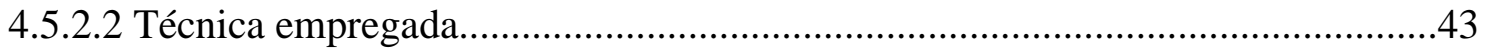

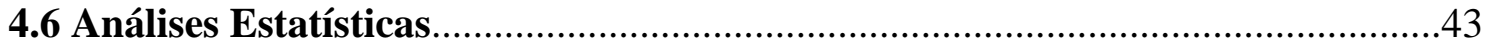

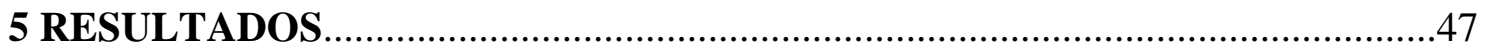

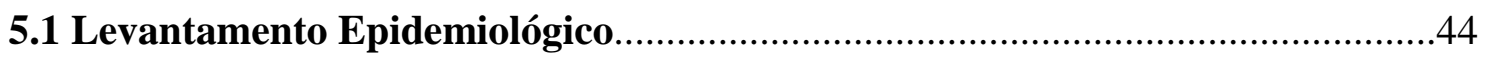

5.2 Avaliação Demográfica da Amostra Estudada por Sorologia para LV .............53

5.3 Reprodutibilidade dos Ensaios Imunoenzimáticos Utilizando antígeno

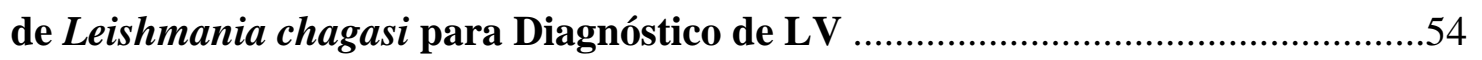

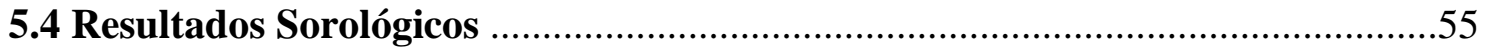

5.5 Comparação Quantitativa dos Testes Sorológicos..............................................57

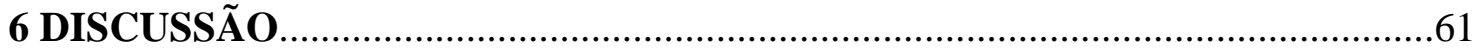

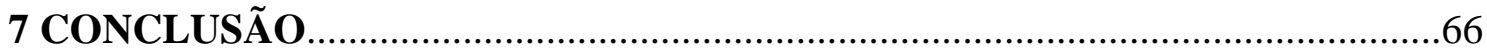

ANEXO - Parecer Consubstanciado Comitê de Ética em Pesquisa........................67

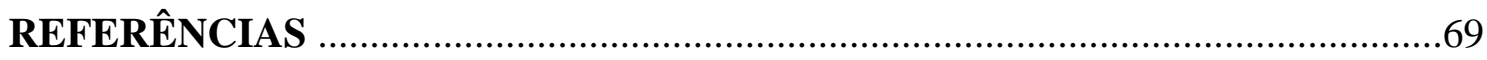




\section{LISTA DE TABELAS}

TABELA 1 - Distribuição dos casos de LV confirmados por municípios da Região Norte do estado do Tocantins segundo o ano de notificação.......44

TABELA 2 - Frequência de casos confirmados de leishmanioses em Araguaína segundo o ano de notificação.

TABELA 3 - Incidência da LVH no município de Araguaína no período de janeiro de 2007 a agosto de 2010 .

TABELA 4 - Distribuição dos casos de LV confirmados por tipo de entrada segundo o ano de notificação.

TABELA 5 - Distribuição dos casos de LV confirmados em Araguaína por sexo segundo o ano de notificação.

TABELA 6 - Distribuição dos casos de LV confirmados por faixa etária segundo o ano de notificação.

TABELA 7 - Distribuição dos casos de LV confirmados por zona de residência segundo o ano de notificação.

TABELA 8 - Distribuição dos casos de LV confirmados por bairros segundo o ano de notificação

TABELA 9 - Distribuições das manifestações Clínicas nos casos de LV confirmados segundo o ano de notificação..

TABELA 10 - Critério de confirmação dos casos de LV confirmados segundo o ano de notificação.

TABELA 11 - Diagnóstico laboratorial dos casos de LV confirmados segundo o ano de notificação.

TABELA 12 - Droga inicial nos casos de LV confirmados segundo o ano de notificação.

TABELA 13 - Evolução dos casos de LV confirmados segundo o ano de notificação.

TABELA 14 - Distribuição da amostra estudada por faixa etária e sexo.

TABELA 15 - Distribuição da frequência dos soros positivos e negativos para a RIFI para LV por tipo final de classificação após os ensaios ELISA Convencional Dissociativo. 
TABELA 16 - Distribuição da frequência dos soros negativos e positivos nas diluições 1:80 e 1:160 para a RIFI para LV por tipo final de classificação após os ensaios ELISA Convencional e o Dissociativo

TABELA 17 - Distribuição da frequência dos soros não-suspeitos, positivos e negativos para a RIFI para LV por tipo final de classificação após os ensaios ELISA Convencional

e o Dissociativo 


\section{LISTA DE FIGURAS}

FIGURA 1 - Frequência de casos confirmados de leishmanioses em Araguaína no período de jan/2007 a ago/2010.

FIGURA 2 - Distribuição dos casos de LV confirmados por faixa etária no período de jan/2007 a ago/2010.

FIGURA 3 - Distribuição dos casos de LV confirmados por bairro no período de jan/2007 a ago/2010.

FIGURA 4 - Distribuição dos casos de LV confirmados por diagnóstico laboratorial período de 2007 a ago/2010

FIGURA 5 - Reprodutibilidade da reação de ELISA in house (convencional)...... .54

FIGURA 6 - Reprodutibilidade da reação de ELISA dissociativo. .55

FIGURA 7 - Distribuição da reatividade dos ensaios de ELISAH e ELISAD .58

FIGURA 8 - Distribuição quantitativa do ELISAH em relação ao resultado qualitativo da IFI

FIGURA 9 - Distribuição quantitativa do ELISAD em relação ao resultado qualitativo da IFI. .60 


\section{LISTA DE ABREVIATURAS E/OU SIGLAS}

ATP Trifosfato de adenosina

CCZ Centro de Controle de Zoonose

DAT Teste de aglutinação direta

DNA Ácido desoxirribonucléico

ELISA Enzyme-Linked Immunosorbent Assay

FDA Food and Drug Administration

GTP Trifosfato de guanosina

HIV Vírus da Imunodefociência Humana

IDRM Intradermorreação de Montenegro

IFI Imunofluorescência Indireta

IL Interleucina

L Leishmania

L. (L.) Leishmania (leishmania)

LTA Leishmaniose tegumentar americana

LV Leishmaniose visceral

LVH Leishmaniose visceral humana

MS Ministério da Saúde

NNN Meio de cultura Novy, Nicolle e Mc Neal

OMS Organização mundial de Saúde

OPD Ortofenilenodiamina

PBS Phosphate buffered saline

PBSTL Phosphate buffered saline + tween + leite desnatado

PCLV Programa de Controle da Leishmaniose Visceral

PCR Reação em cadeia de polimerase 
RIFI Reação de Imunofluorescência Indireta

$\mathrm{SB}^{\mathrm{v}} \quad$ Antimonial pentavalente

SESAU Secretaria de Saúde do Tocantins

SINANNET Sistema de Notificações de Agravos

TDR1 Tripanotiona redutase

TGO Aminotransferase glutâmico-oxalacética

TGP Transaminase glutâmico pirúvica

Th Linfócito T helper

TNF- $\alpha \quad$ Fator de necrose tumoral alfa

TRALD Teste rápido imunocromatográfico

TRIS Tris-hidroximetilaminometano 


\section{INTRODUÇÃO}

As leishmanias são protozoários patogênicos do filo Kinetoplastidae, que causam doenças em vertebrados, incluindo o homem (Lainson e Shaw, 1987).

Apresentam-se de duas formas diferentes: promastigota, que se locomove por meio de flagelo no trato digestivo do vetor e em meios de cultura, ou na forma amastigota (imóvel) no interior dos macrófagos do hospedeiro, sendo que suas principais estruturas celulares não variam entre as duas formas. A membrana plasmática é simples com uma invaginação na sua parte posterior de onde sai o flagelo, e também onde se localizam o desmossomo, organela responsável pela fixação do parasita às outras células. Dentro do citoplasma, localizam-se estruturas semelhantes às das células humanas como mitocôndrias, aparelho de Golgi, retículo endoplasmático rugoso, além de algumas outras organelas como, por exemplo, vesículas de gordura, cinetoplasto e corpo parabasal de onde sai o flagelo, acantossomo, glicossomo, corpo multivesiculado e vacúolo. O núcleo possui uma carioteca e nucléolos (Vickerman, 1974).

Seu metabolismo para obtenção de energia, quando na fase promastigota, é estritamente aeróbio, e quando submetido a meios sem presença de oxigênio demonstra uma brusca redução de suas atividades como, por exemplo, a degradação de glicose. Suas mitocôndrias se utilizam de glicólise e oxidação de prolinas para a formação de ATP, sua forma de armazenar energia (Alvárez-Fortes et al, 1998).

As leishmanias ao serem fagocitadas pelos macrófagos permanecem em um vacúolo fagolisossomal onde deveriam ser degeneradas. Porém, as moléculas responsáveis pela captação e apresentação do antígeno, são reconhecidas e degradadas pelas Leishmanias impedindo assim que o mecanismo de destruição seja interrompido. Essas moléculas são moléculas apresentadoras de antígeno MHC classe II, e sabe-se que elas são as principais responsáveis pelo processo de reconhecimento de antígenos para a maioria das espécies de Leishmania, inclusive a L. amazonensis. Assim, o parasita consegue multiplicar-se e disseminar-se por todo tecido sem ser destruído (Antoine et al, 1999). As primeiras lesões aparecem após, aproximadamente, um mês de incubação.

Há diversos tipos clínicos de leishmaniose: uma infecção cutânea simples que pode curar-se espontaneamente, uma forma mucocutânea (em que pode haver grandes 
úlceras das membranas mucosas) e uma forma visceral (calazar). As doenças causadas por esses agentes são espectrais em sua apresentação clínica. Uma porcentagem relevante dos pacientes não apresenta doença clínica significativa, apesar de evidência sorológica de infecção. Outros apresentam doença disseminada, como na leishmaniose cutânea difusa ou na leishmaniose visceral (LV). Outros, por sua vez, apresentam lesão imunopatológica extensa, como na leishmaniose cutâneo-mucosa, com resposta exacerbada aos poucos antígenos e parasitas existentes (Neves et al, 2005).

A Organização Mundial da Saúde (OMS) estima que 300 milhões de pessoas estejam em risco de contrair leishmaniose, com cerca de dois milhões de casos novos por ano, sendo incluída como uma das principais endemias mundiais (Ministério da Saúde, 2008).

A LV no Brasil é um problema de saúde pública, pois já foram registrados casos autóctones em 19 dos 27 estados brasileiros. A Região Nordeste concentra mais de 90\% dos casos humanos da doença. O aparecimento de focos importantes nas Regiões Norte, Sudeste e Centro-Oeste tem contribuído para uma crescente prevalência, com uma média anual nos últimos cinco anos de 3.500 casos (Marzochi et al, 2008).

No Estado do Tocantins, em decorrência de modificações ecoepidemiológicas, como a construção de Palmas, capital do Estado; o interesse nas atividades ligadas à penetração das matas; a manutenção de hábitos simples pelas populações, como o da criação de animais nos quintais; a presença comum de animais soltos nas ruas das cidades interioranas; a invasão da floresta pelo perímetro urbano; o intenso fluxo migratório e a falta de estrutura básica e sanitária propiciaram a urbanização do vetor e propagação da doença (Cimerman et al, 2003).

Desde 2005, o município de Araguaína vem obtendo os maiores números de notificações do Tocantins, conforme o Sistema de Notificações de Agravos (SINANNET). Em 2007, foram notificados 392 casos novos confirmados de leishmaniose visceral humana (LVH) no Estado, sendo que destes, 205 em Araguaína, correspondendo a 52\% do total de casos do estado, sendo assim considerado um município de transmissão intensa (Secretaria Municipal de Saúde, 2008).

Estudos de prevenção mostraram que o vetor e outros reservatórios são passíveis de controle, mas a um alto custo econômico e social. Estudos vacinais têm 
apresentado resultados conflitantes utilizando diferentes preparações antigênicas (Gontijo, 2004).

O prognóstico é ruim para pacientes não-tratados, havendo mortalidade da ordem de 75 a 85\%, entre as crianças, e de 90 a 95\%, entre os adultos (Marzochi et al, 2008). O regime terapêutico de primeira escolha para o tratamento da LV é baseado na utilização dos antimoniais pentavalentes, porém, a necessidade de 28 dias de administração parenteral, a presença de reações adversas severas, a eficácia variável e o aparecimento de resistência são os fatores que limitam o uso destes medicamentos. No entanto, os medicamentos disponíveis para o tratamento são restritos, alguns como o desoxicolato de anfotericina $\mathrm{B}$, formulações lipídicas de anfotericina $\mathrm{B}$, miltefosina e paromomicina têm limitações em termos de toxicidade, eficácia variável, preços e esquemas de tratamento inconvenientes (Borborema, 2009).

A detecção do parasita constitui o requisito básico para o diagnóstico da LV. A pesquisa deste por biópsia ou punção aspirativa do baço, fígado, linfonodo ou medula óssea constitui um procedimento invasivo, oferecendo riscos ao paciente, e exigem ambiente apropriado e pessoal treinado para a coleta. Os testes sorológicos têm suas limitações, pois não conferem 100\% de especificidade e sensibilidade. Apresentam reações cruzadas com outras infecções, como malária e Doença de Chagas. Por outro lado, a presença de imunocomplexos no soro de pacientes doentes leva a resultados falsonegativos, e consequentemente agrava o quadro clínico, caso o tratamento farmacológico não seja estabelecido. Um grande passo para se alcançar está na melhoria da distribuição e da capacidade de resolução diagnóstica da LV nos municípios. Por isso, é imprescindível o desenvolvimento de estudos que visam a elaborar técnicas de diagnósticos sorológicos da LV humana e canina mais específicos, que sejam ao mesmo tempo simples, rápidos e de baixo custo, fazendo jus à realidade dos municípios mais afetados (Malafaia, 2009).

$\mathrm{O}$ ineditismo do trabalho reside em um levantamento epidemiológico que mostre a situação atual da LV no município de Araguaína que contribuirá para que as ações propostas pelo Programa de Controle da Leishmaniose Visceral (PCLV) do Brasil sejam efetivas no município; adicionalmente, considerando-se que não existe ainda um sistema disponível com comprovada aplicabilidade que determine a administração do tratamento, qualquer iniciativa no sentido de desenvolver ensaios que identifiquem pacientes com LV contribuirá sobremaneira para o diagnóstico e terapia da doença. 


\section{OBJETIVOS}

\subsection{Geral}

- Avaliar o quadro da Leishmaniose Visceral Humana no município de Araguaína (TO) no período de janeiro de 2007 a agosto de 2010.

\subsection{Específicos}

- Realizar levantamento dos casos de Leishmaniose Visceral Humana no município de Araguaína, ressaltando sua importância epidemiológica;

- Comparar abordagens diagnósticas sorológicas em amostras de pacientes de Araguaína, separados por sua condição clínica;

- Diminuir casuística de falsos negativos freqüentes em abordagens diagnósticas sorológicas. 


\section{REVISÃO DE LITERATURA}

\subsection{Conceito}

A Leishmaniose visceral (LV) é uma doença causada por parasitas do complexo Leishmania donovani, na África, Ásia, Europa e nas Américas. Na Índia é conhecida como Kalazar, palavra de origem indiana que em sânscrito significa "doença negra", febre Dum-Dum. Na região do Mediterrâneo é chamada leishmaniose visceral infantil e na América Latina, leishmaniose visceral americana (LVA) ou calazar neotropical. A doença é crônica, grave de alta letalidade se não tratada, e apresenta aspectos clínicos e epidemiológicos diversos e característicos, para cada região onde ocorre. Os fatores de riscos para o desenvolvimento da doença incluem a desnutrição, o uso de drogas imunossupressoras e a co-infecção com o vírus da imunodeficiência humana (HIV) (Michalick et al, 2005).

\subsection{Aspectos Históricos}

A primeira observação dos parasitas que causavam a LV ocorreu na Índia por Cunningham (1885) em indivíduos acometidos pela doença. Posteriormente, em 1903, o agente etiológico foi descrito quase simultaneamente por William Leishman e Charles Donovan. Leishman observou pequenos corpúsculos ovais, com 2-3 mm de diâmetro, em preparações obtidas do baço de um soldado inglês que havia morrido de febre Dum-Dum, contraída em Calcutá, Índia. Ainda em 1903, Laveran e Mesnil, considerando que o parasita associado ao calazar indiano fosse um piroplasma, nomeou-o Piroplasma donovani. Ross, nesse mesmo ano, criou o gênero leishmania, denominado Leishmania donovani. O parasita foi encontrado em cães pela primeira vez na Tunísia em 1908 por Nicole e Comte ( Michalik et al, 2005).

Pena, em 1934, relatou os primeiros encontros do parasita no Brasil, em lâminas de cortes histológicos de fígado, para o diagnóstico anatomopatológico de febre amarela, obtidos de indivíduos oriundos das Regiões Norte e Nordeste. A partir de 1953 e 
até 1965 , a doença foi estudada em algumas regiões do país, ficando demonstrado seu caráter endêmico (Neves et al, 2005).

No Brasil, embora Penna houvesse relatado a existência da doença a partir de material de viscerotomia post-mortem praticada para confirmação de óbitos por febre amarela, em vários estados da região Nordeste, o primeiro caso diagnosticado in vivo foi relatado por Evandro Chagas, em 1936. No ano seguinte, Chagas e seus colaboradores denominaram o parasita de Leishmania donovani chagasi, embora a origem da Leishmania chagasi ainda seja motivo de controvérsia, podendo ser considerada indígena, no Novo Mundo ( espécie L. Chagasi ou L. donovani chagasi) ou introduzida pelos colonizadores ( L.d. infantum ou Leishmania infantum, agente da L.V. tipo mediterrâneo) ou apresentar mais de um parasita envolvido (Cimerman et al, 2003).

Nas décadas de 50 e 60, enquanto Rodrigues da Silva (1957) e Prata (1957, 1963) realizam importantes contribuições com estudos clínicos e terapêuticos, o casal Deane desenvolve pesquisas fundamentais sobre reservatórios naturais da doença, apontando-a como uma zoonose (Cimerman et al, 2003).

\subsection{Epidemiologia}

Focos da doença têm sido descritos em todos os continentes, à exceção da Oceania. Estima-se que existam 12 milhões de pessoas infectadas em todo o mundo, com aproximadamente 600.000 novos casos notificados por ano (Scodro, 2008).

Segundo a OMS, globalmente, há uma estimativa anual de 70.000 mortes e 350 milhões de pessoas expostas ao risco de infecção e doença. A morbidade e mortalidade por causa das leishmanioses causam cerca de 2,4 milhões de anos perdidos por incapacidade. (Borborema, 2009).

A LV é uma doença própria de zonas rurais, sendo endêmica em 62 países localizados nas regiões tropicais e subtropicais da Ásia, Oriente Médio, África, América Central e América do Sul. Nessas regiões estima-se uma população em torno de 200 milhões de pessoas em risco de contrair a infecção e cerca de 500 mil novos casos por ano (Sena et al, 2010).

Na América Latina, a doença já foi descrita em pelo menos 12 países, sendo que $90 \%$ dos casos ocorrem no Brasil, especialmente na Região Nordeste. O registro do 
primeiro caso da doença no Brasil ocorreu em 1913, quando Migone, no Paraguai, descreveu o primeiro caso em material de necropsia de paciente oriundo de Boa Esperança, Mato Grosso. Desde então, a transmissão da doença vem sendo descrita em vários municípios, de todas as regiões do Brasil (Ministério da Saúde, 2001).

A doença tem apresentado mudanças importantes no padrão de transmissão. Inicialmente, predominado pelas características de ambientes rurais e periurbanas e, depois, em centros urbanos como Rio de Janeiro (RJ), Corumbá (MS), Belo Horizonte (MG), Araçatuba (SP), Palmas (TO), Três Lagoas (MS), Campo Grande (MS), entre outros. No Brasil a LV está registrada, com aproximadamente 1.600 municípios apresentando transmissão autóctone (Alves et al, 1996).

A partir dos anos 90, os estados do Pará, Tocantins, Mato Grosso do Sul, Minas Gerais e São Paulo passaram a contribuir significativamente nas estatísticas dos casos de LVH no Brasil (Gontijo et al, 2004).

No Estado do Tocantins, localizado na região Norte do país, Araguaína destaca-se pela alta incidência da patologia em relação a outros municípios do Estado e do Brasil. $\mathrm{O}$ aumento do número de casos nos locais onde a LV ocorre também é favorecido pela presença de fatores de riscos individuais que facilitam a evolução de infecções para doenças como desnutrição, imunossupressão relacionada ao uso de drogas imunossupressoras, transplantes de órgão e a co-infecção com HIV; e o desenvolvimento de projetos que trazem seres humanos não imunes para dentro de áreas endêmicas, como construção de estradas, turismo, assentamento, atividades militares, entre outros (Machado, 2004; Rebelo, 2001).

Segundo a Divisão de Vigilância Epidemiológica da Secretaria Municipal de Saúde de Araguaína foi observado um significativo aumento no número de casos de LV neste município.

O único vetor incriminado comprovadamente na transmissão de LV no Brasil é o Lutzomya longipalpis, cuja distribuição se superpõe às áreas endêmicas ou aos focos conhecidos. A taxa de infecção natural no flebotomíneo é sempre baixa, mesmo nas áreas endêmicas, e a transmissão depende da elevada densidade de Lutzomya longipalpis, como se observa durante surtos da doença. A aplicação de inseticidas nas paredes do domicílio e anexos reduz drasticamente a transmissão (Cimerman et al, 2003). 
As raposas, pelo seu intenso parasitismo, podem ser responsáveis pela disseminação da protozoonose para locais distantes devido aos seus hábitos migratórios. Na Amazônia, o Cerdocyon thous apesar do elevado parasitismo, não apresenta sintomas, sendo considerada importante fonte silvestre da Leishmaniose chagasi na região, ao contrário da Lycalopex vetulus, no Nordeste, que contrai infecção grave e mortal (Rosas Filho et al, 2007).

Os cães são reservatórios domésticos, encontrados infectados em todos os focos da doença humana, são considerados o principal elo na cadeia de transmissão do calazar. De 1980 a 1997, foram examinados 8.418.519 cães pelo Ministério da Saúde em áreas endêmicas e cerca de 206.000 estavam infectados (Alves, 2008).

Nos reservatórios animais, cão e raposa, o parasitismo cutâneo é geralmente intenso e não é raro o isolamento de parasitas do sangue. São excelentes fonte de infecção para flebotomíneos, mantendo o ciclo da doença no ambiente domiciliar e silvestre, respectivamente (Sousa et al, 2008).

No Brasil, a importância do cão como principal reservatório da doença tem sido questionada nos últimos anos. Os principais argumentos são: a) a falta de correlação espacial entre a incidência cumulativa da LV humana e a soroprevalência da doença em cães; b) a ausência e/ou baixa correlação entre a coabitação com cães e aquisição de LV; c) estudos mostrando que a eliminação de cães como medida isolada de controle não foi suficiente para produzir uma redução na incidência da infecção e doença na população humana (Costa, 2005).

Outro aspecto novo e preocupante é a urbanização da doença que expandiu suas áreas de transmissão para as periferias dos grandes centros urbanos como demonstram os surtos registrados em Teresina, Natal, São Luís, Fortaleza, Camaçari-BA, Montes Claros-MG, Belo Horizonte e Rio de Janeiro (Tonello et al, 2007).

Tanto na doença causada pela $L$. (L.) infantum quanto na causada pela $L$. (L.) chagasi a faixa etária mais acometida é a pediátrica e a boa resposta terapêutica é uma das características deste grupo epidemiológico. A leishmaníase dérmica pós-calazar é um evento raro. A proporção de indivíduos infectados que desenvolvem sinais e sintomas da doença é de aproximadamente 18:1(Filho \& Silveira, 2007). 


\section{Co-infecção Leishmaniose Visceral Humana e HIV}

Dos 88 países endêmicos para LV em todo o mundo, 33 já relataram casos da co-infecção LV-HIV. Na Europa, 25-70\% dos casos de LV estão associados ao HIV e 1,59\% dos casos de aids desenvolvem ao longo da vida LV, quer seja por infecção natural ou reativação de uma infectante latente. Dos 1.700 casos notificados até final de 1998, 1.440 eram do continente europeu: 835 da Espanha, 229 da Itália, 259 da França e 117 de Portugal. A distribuição por sexo e faixa etária mostrou que a maioria deles $(83,2 \%)$ ocorreu no sexo masculino, $85,7 \%$ eram adultos (20-40 anos) e 71,1\% eram usuários de drogas injetáveis. No Brasil, o número casos da co-infecção ainda é pequeno (aproximadamente 40 casos até o início de 2001), mas o aumento da incidência e a ruralização dos casos de HIV e a urbanização da LV certamente irão aumentar o número de casos desta co-infecção no país (Sena, 2010).

\subsection{Etiologia}

A LVH é causada por espécies de Leishmania caracterizadas por critérios fenotípicos e genotípicos, comportamento nos insetos vetores, virulência, características de cultivos in vitro de imunidade cruzada, reatividades com isoenzimas, análise de ácidos graxos, padrão de digestão da sequência ribossomal e do DNA do cinetoplasto (kDNA) através de enzimas de restrição, de lectinas que se ligam à membrana celular e hibridação de ácidos nucléicos (Brasil, 2005).

A taxonomia das leishmanias é assunto controverso. Em 1987, foi proposta uma classificação das espécies baseada no desenvolvimento dos parasitas no tubo digestivo do vetor, no comportamento em animais de laboratório e no perfil imunológico e bioquímico dos protozoários. Atualmente, são reconhecidas como causadoras da LV, as espécies Leishmania (Leishmania) chagasi, no Novo Mundo, Leishmania (Leishmania) infantum, na região do Mediterrâneo, Leishmania (Leishmania) donovani, na Índia, Oriente, África Central e Oriental (Gontijo et al, 2004).

A Leishmania (Leishmania) chagasi difere da Leishmania (Leishmania) donovani pelo perfil imunoenzimático e pela sorotipagem de fatores de excreção. Essas duas espécies podem ser diferenciadas da Leishmania (Leishmania) infantum pela 
densidade de flutuação do kDNA, pelo perfil radioespirométrico e pelo padrão de restrição do kDNA (Gontijo et al, 2004).

No hospedeiro vertebrado, as leishmanias assumem as formas de amastigotas e são parasitas intracelulares obrigatórios. Nas células do sistema fagocitário mononuclear (SFM) dos hospedeiros vertebrados, multiplicam-se e podem destruir as células parasitadas. Uma vez livres, as amastigotas podem ser fagocitadas por outras células do hospedeiro ou são ingeridas pelo vetor, no momento do seu repasto sanguíneo. No tubo digestivo do vetor, transforma-se em formas flageladas que sofrem uma série de transformações e evoluem para forma flagelar metacíclica que migra para probóscida do inseto de onde são regurgitadas no momento da picada, quando, como formas promastigotas, infectam os mamíferos, fechando o ciclo evolutivo. Substâncias contidas na saliva dos insetos vetores aumentam a infectividade das leishmanias (Marzochi et al, 2008).

As promastigotas são fagocitadas pelos macrófagos e a acidez, dentro do fagolisossoma, os induzem a se transformarem em amastigotas arredondadas que perdem os flagelos, porém contêm uma única mitocôndria especializada contendo DNA denominado cinetoplasto. As amastigotas proliferam-se dentro dos macrófagos, e a destruição dos macrófagos libera uma geração de amastigotas que podem infectar macrófagos adicionais (Marzochi et al, 2008).

\subsection{Patogenia}

A doença pode ter desenvolvimento abrupto ou gradual. Os sinais sistêmicos típicos estão associados à febre intermitente, palidez da mucosa, esplenomegalia associada ou não a hepatomegalia, e progressivo emagrecimento com enfraquecimento geral do hospedeiro. Na doença abruta e nos pacientes portadores do HIV, o óbito pode ocorrer, antes que os sintomas sejam desenvolvidos. Os sinais mais frequentes são hemorragia gástrica e ictérica. A relação parasita/hospedeiro assume caráter espectral e é possível atribuir formas clínicas, variando de uma forma silenciosa assintomática, considerada subclínica, ou oligossintomáticas, forma aguda até a forma crônica ou de evolução clássica (Michalick, 2005). 
Os parasitas causadores da LV determinam três tipos de resposta frente à infecção: resolução do processo infeccioso, com destruição local e eliminação dos parasitas; resposta tecidual com fagocitose dos parasitas e persistência dos mesmos sobe a forma latente; disseminação dos parasitas para órgãos ricos em células do sistema fagocitário mononuclear, na dependência de fatores de risco como associação com outras doenças, infecções respiratórias, desnutrição e estado imunitário (Duarte, 2000).

\subsubsection{Aspectos clínicos}

- Período de incubação

Sua duração é muito variável, situando-se entre dois e quatro meses, nos casos estudados no Ceará. A literatura mundial registra casos que vão de dez dias a três anos (Moreno et al, 2002).

- Fase inicial da doença

No local da picada dos insetos vetores pode formar-se pequeno nódulo endurecido (de alguns milímetros) que se apresenta externamente como uma pápula, de cor pálida ou ligeiramente pigmentada. Geralmente, a LV ou começa de modo gradual, imperceptivelmente, com adinamia, anorexia, palidez e ligeiro aumento do baço, com elevação da temperatura, ou então de forma abrupta, com febre alta $\left(39,5-40^{\circ} \mathrm{C}\right)$, contínua ou não, lembrando infecções intestinais, febre tifóide ou malária. Neste período pode haver eosinofilia (Melo, 2004).

- Decurso da doença

A febre é o sintoma mais notável, pela sua constância, sendo de tipo irregular ou remitente. Em muitos casos, a curva febril mostra um duplo ascenso diário. Mas há, também, casos subfebris ou com hipertermia $\left(40-41{ }^{\circ} \mathrm{C}\right)$, acompanhada de pulso rápido, palidez e astenia. A esplenomegalia é a segunda manifestação em importância. $\mathrm{O}$ volume do baço aumenta com relativa rapidez, tanto em crianças como em adultos, e pode ultrapassar a cicatriz umbilical. Sua consistência é dura e, mesmo sendo indolor à palpação, causa uma sensação de dor pela distensão de sua cápsula. O aumento do fígado costuma ser em escala menor que o baço. Há, quase sempre, micropoliadenia. Nos casos 
não tratados, a esplenomegalia segue aumentando, ao mesmo tempo em que cresce o esgotamento geral e a atonia muscular. No entanto, com tratamento bem conduzido, seguese notável redução do baço e do fígado (Machado, 2004).

Com o progredir da doença, acentua-se a anemia e há marcada tendência às hemorragias. As epistaxes são frequentes, assim como as hemorragias gengivais ou digestivas e, algumas vezes, há petéquias. Pode haver edema da pele, bem como hiperpigmentação. Aparecem comumente tosse; raramente broncopneumonia. As perturbações do apetite e o emagrecimento tendem a conduzir, progressivamente, a um estado de desnutrição grave (Neves et al, 2005).

A evolução da doença pode ser rápida, levando o paciente à caquexia e à morte dentro de algumas semanas ou de alguns meses; ou assumir um curso crônico. O desfecho sobrevém muitas vezes, por doenças intercorrentes num organismo cujos mecanismos imunológicos já se encontram comprometidos (Moreno et al, 2002).

\subsubsection{Formas clínicas}

Costuma-se distinguir, segundo a sintomatologia e a evolução, as seguintes formas de LV, cujos limites são naturalmente convencionais, pois o quadro clínico pode evoluir de uma para outra (Rey et al, 2005).

- Forma subclínica ou infecção inaparente

Caracteriza-se pela ausência de manifestações clínicas, presença de anticorpos antileishmania e/ou intradermorreação de Montenegro (IDRM) positiva. A ausência de manifestações clínicas é estabelecida a partir de anamnese negativa e exame físico normal. Pode equivaler ao processo infeccioso inicial que evoluirá à doença ou a fase de involução do processo inicia-se de caráter auto-resolutivo (relação ideal de equilíbrio parasitahospedeiro) ou ao resíduo imune pós-doença em casos tratados. A forma inaparente só pode ser detectada pela busca ativa dos casos. O tratamento normalmente não está indicado (Cimerman et al, 2003). 
- Forma Leve

Caracteriza-se, de regra, pela ausência de sintomas (indivíduos sem queixas) e, se eventualmente presentes, são esporádicos e difíceis de serem associados à LV. Presença de sinais ao exame físico, discreta hepatomegalia e/ou esplenomegalia, presença de anticorpos antileishmania, IDRM provavelmente positiva, com ou sem evidenciação de leishmania por punção de órgãos. Pode involuir à forma inaparente ou evoluir para as formas sintomática e grave. A IDRM, se eventualmente negativa, poderá ser um sinal de alerta a esta possibilidade. A forma leve também é encontrada por meio da busca ativa. $\mathrm{O}$ tratamento desses casos poderá deixar de ser efetuado apenas quando for assegurado o acompanhamento clínico por longo período (Cimerman et al, 2003).

- Forma Moderada

Caracteriza-se por história clínica de semanas a poucos meses, de febre variável, episódios de diarréias, eventualmente outras manifestações, porém com estado geral mantido, atividade normal nos períodos sem febre, presença de hepatoesplenomegalia discreta a moderada, teste sorológicos positivos, IDRM eventualmente positiva e evidenciação de leishmania por hemocultura. Os exames laboratoriais hematológicos e bioquímicos apresentam-se moderadamente alterados. Os pacientes tratados com antimonial costumam evoluir bem, sem complicações. Não-tratados devem evoluir, progressivamente, para o agravamento do quadro clínico (Marzochi et al, 2001).

- Forma Grave

Caracteriza-se por evolução insidiosa, resultante de diagnóstico tardio, em que os pacientes referem história de meses, até ano de doença, levando progressivamente a um quadro consumptivo, acompanhado de febre de caráter variável e crescente adinamia, palidez, perda de peso, aumento do volume abdominal, ocorrência de episódios de sangramentos e diarréicos, e outras manifestações. Os exames clínicos e laboratoriais inespecíficos evidenciam grave comprometimento geral, hepatoesplenomegalia volumosa, anemia evoluindo à pancitopenia e hipoalbuminemia (com inversão albumina/globulina) acentuada, alterações moderadas de outras provas de função hepática e de testes de função renal; essas alterações progridem paralelamente ao agravamento clínico com insuficiência cardíaca e edemas até a anasarca, emagrecimento até a caquexia, hemorragias de mucosas 
ou de pele tipo petequial predominante em áreas de atritos e membros inferiores, icterícia leve a moderada, hipertensão arterial (em geral em picos) e infecções bacterianas secundárias (Cimerman et al, 2003).

Os títulos de anticorpos são muito elevados, a IDRM é negativa, e as leishmanias são evidenciadas por punção de medula óssea ou outros métodos. O óbito ocorre nesta fase devido ao tratamento tardio ou à ausência de resposta ao antimonial e a outras drogas, em geral associada às complicações. Está frequentemente associada à septicemia bacteriana e/ou hemorragia grave, que pode levar a óbito antes mesmo do início do tratamento da leishmaniose ou nos primeiros dias de iniciado (Lima, 2001).

\subsubsection{Co-infecção Leishmaniose Visceral / Vírus Imunodeficiência Humana (HIV)}

Quando a LV é infecção oportunista, nestes casos as manifestações clínicas são atípicas, como ausência de esplenomegalia e falta de resposta ao tratamento com antimoniais (Lachaud et al, 2000).

\subsubsection{Leishmaníase dérmica pós-calazar}

Na LV da Índia e do Sudão, 10 a $20 \%$ dos pacientes que não receberam tratamento ou, mesmo, alguns dos que foram tratados passam a apresentar leishmânides, isto é, lesões secundárias tardias, meses ou anos depois da recuperação. Essas lesões aparecem na pele do rosto, membros e outras partes do corpo, sob a forma de discromias, de máculas eritematosas, de pequenos nódulos ou de papilomas contendo leishmanias (lembrando a hanseníase lepromatosa), com tendência crônica e expansiva. Elas constituem manifestações secundárias da infecção por leishmania donovani, não ocorrendo na leishmaniose infantil produzida por leishmania infantum (Medeiros et al, 2005). 


\subsection{Relação Hospedeiro Versus Parasita}

\subsubsection{Infectividade e Resistência}

Os flebotomíneos infectam novos hospedeiros vertebrados mediante inoculação pela picada. O poder infectante parece depender da cepa do parasita, da abundância de reservatórios da infecção na área, e de insetos vetores adequados, bem como de circunstâncias, como a suscetibilidade dos novos hospedeiros (Rey L, 2001).

Quanto às estirpes de animais suscetíveis, observa-se que a evolução de sua infecção pode ser muito diversa. Alguns animais, depois de infectados, conseguem pôr em marcha mecanismos imunológicos capazes de controlar a infecção em prazos razoáveis, enquanto outros não podem fazê-lo e o processo infeccioso progride, então, continuamente, sem limites, até produzir a morte do hospedeiro. Os animais que se curam desenvolvem forte capacidade de responder com uma reação de hipersensibilidade retardada e seus macrófagos mostram-se capazes, in vitro, de destruir leishmanias. Pôde-se demonstrar que essa resposta é timo-dependente (Rey et al, 2005).

\subsubsection{Imunidade adquirida}

Assim como outras doenças multifatoriais de trato complexo, a resposta do homem à infecção por leishmanias do complexo L. donovani é muito complexa. No local da picada infectante do inseto, desenvolve-se um processo inflamatório com formação de pápula ou nódulo de base dura que alguns casos, evolui para cura. Em condições naturais, nem todas as infecções evoluem para o tipo visceral, a maioria delas têm evolução benigna, assintomática e com cura espontânea. Em áreas endêmicas do Brasil, constatou-se que a proporção de indivíduos infectados para indivíduos doentes varia de 5:1 a 18:1. As infecções benignas também conferem imunidade, impedindo muitas das pessoas sujeitas ao risco de contágio, nas áreas endêmicas, de adoecerem quando recebam uma estirpe mais virulenta do parasita (Reis et al, 2006). Dois tipos de resposta imunológica podem ser observados, a imunidade humoral, que se traduz pela elevação do teor de gamaglobulinas no soro e pelas reações sorológicas positivas, e a celular. Anticorpos específicos são produzidos durante a infecção, mas não asseguram proteção contra o parasitismo. Há uma 
super produção de imunoglobulinas (Ig) pelo sistema imunológico que se encontra desregulado e fabrica grandes quantidades de anticorpos inespecíficos (Nascimento et al, 2006). No homem, o título de Ig eleva-se rapidamente (particularmente o de Ig G) e as gamaglobulinas podem chegar a representar $50 \%$ do total de proteínas séricas. Mas logo que os sinais e sintomas desaparecem, caem os títulos (rapidamente também), mantendose, entretanto, positivos por vários anos, na grande maioria dos casos tratados (Schubach, 2001).

A imunidade celular, que pode ser demonstrada com a reação da leishmanina (ou reação de Montenegro), é feita injetando-se intradermicamente o antígeno leishmanina, constituído por uma suspensão de culturas mortas de Leishmania. Na LV assim como na leishmaniose tegumentar difusa, o teste da leishmanina permanece negativo durante o curso da doença que só se torna positivo por ocasião da cura. Ele é, pois, um indicador importante para o prognóstico. Os macrófagos são afetados pela LV, ocorrendo um desequilíbrio das vias de ativação linfócito T helper tipo 2 (Th2), com diminuição da resposta Thelper tipo 1 (Th1) protetora. A interleucina 2 (IL2), interleucina 12 (IL12) e o interferon-gama ficam diminuídos, enquanto se elevam a interleucina 4 (IL4) e o fator de necrose tumoral, cujo nível parece estar relacionado com a gravidade da doença. Também ficam diminuídos os receptores eritrocitários tipo 1 do complemento (Serafim et al, 2006). A supressão da resposta mediada por linfócitos $\mathrm{T}$, tanto a mitógenos como a antígenos de leishmania, altera profundamente a imunidade celular, sobretudo a hipersensibilidade celular de tipo IV (Rey et al, 2005).

\subsubsection{Imunocomplexos}

A resposta humoral com a estimulação dos linfócitos B se traduz numa elevada concentração de globulinas não específicas. Estas dão lugar a presença de imunocomplexos, compostos principalmente pelas IgG e fracções C1, C2 e C4 do complemento em vários locais do organismo e que são responsáveis por muitos sintomas mais graves da doença (Reiche et al, 2006).

A produção de imunocomplexos circulantes que se depositam nos glomérulos renais, vasos e articulações, como consequência da persistência dos antígenos circulantes provoca uma estimulação antigênica crônica (Chaves-Borges et al,1999). 


\subsection{Diagnóstico}

O encontro do parasita constitui o requisito básico para o diagnóstico da LV. A sorologia é útil para uma triagem de casos, quando for difícil demonstrar a presença de leishmanias, bem como em inquéritos epidemiológicos. A dosagem de proteínas e a eletroforese do soro, com alteração da relação albumina/globulina e hipergamaglobulinemia acentuada, são bastante sugestivas, bem como hemograma, acusando anemia, leucopenia, monocitose e linfocitose (Costas et al, 2007).

\subsubsection{Diagnóstico Clínico}

Baseia-se nos sinais e sintomas apresentados pelos pacientes associados à história de residência em área endêmica. Entretanto, é preciso especial atenção para outras doenças que apresentam sintomatologia semelhante, como malária, toxoplasmose, brucelose, tuberculose e esquistossomose, principalmente em áreas onde ocorre a superposição na distribuição das doenças (Reiche et al, 2006).

Nos pacientes com aids, portadores do vírus HIV, de doenças malignas como linfomas e lúpus eritematoso sistêmico, e naqueles submetidos a transplante de órgãos, em uso de drogas contra a rejeição, os sinais e sintomas da LV podem ser influenciados e modificados, de forma que as manifestações clínicas não mantenham as suas características. Em particular, nos pacientes com aids, os sintomas mais relatados são as lesões de pele, manifestações hemorrágicas gastrintestinais e respiratórias, por vezes, na completa ausência de febre e esplenomegalia (Brasil, 2004).

\subsubsection{Diagnóstico Laboratorial}

\subsubsection{Métodos parasitológicos}

As leishmanias podem ser encontradas no interior de células fagocitárias fixas ou livres, sendo reconhecidas por sua morfologia de amastigotas. Elas devem ser distinguidas das formas amastigotas de Trypanossoma cruzi e dos trofozoítas de Toxoplasma. O material para exame pode ser recolhido de vários órgãos (Costa et al, 2007). 
- Punção das vísceras

Os parasitas podem ser encontrados no material aspirado do baço (98\% dos casos dão resultados positivos), da medula óssea (54 a 86\% de positivos) ou de linfonodos aumentados de volume (64\% dos casos). A punção da medula óssea é a técnica mais simples e representa menos risco para o paciente. No adulto, é realizada na medula do esterno, no segundo espaço intercostal e em crianças, na crista ilíaca. O cultivo do aspirado pode melhorar a positividade do resultado e a segurança do diagnóstico, entretanto é raramente usado na rotina da prática clínica, pois o crescimento dos parasitas pode levar dias ou semanas (Neves, 2005). Com o material aspirado, preparar esfregaço (estendido em lâmina de microscopia), fixar e corar pelo método de Giemsa, ou por método equivalente (Brasil, 2005).

- Pesquisa de leishmanias no sangue

Elas podem ser encontradas, eventualmente, no interior de leucócitos, devendo a pesquisa ser feita no creme leucocitário, obtido por centrifugação de amostra de sangue em tubo capilar. Fixar e corar pelo método de Giemsa, ou por método equivalente (Rey et al, 2005).

- Pesquisa de leishmanias na pele

Tal como o exame de sangue, esta pesquisa não faz parte da rotina diagnóstica, devido à escassez de parasitas na pele, exceto nos casos de leishmaníase dérmica póscalazar. A escarificação da pele não deve provocar sangramento. Com o material obtido faz-se um esfregaço ou, no caso de biópsia, uma impressão sobre lâmina de microscopia, e se cora pelo método de Giemsa (Genaro, 2003).

- Cultura em meio Novy, Nicolle e McNeal (NNN)

Sempre que a escassez de parasitas dificultar sua busca ao microscópio, o material suspeito deve ser semeado no meio de NNN. As culturas, incubadas a $24^{\circ}-26^{\circ} \mathrm{C}$, devem ser examinadas 5, 7 ou 10 dias depois; mas, caso sigam negativas, repicar para novo meio após 15 dias. Essa demora para a obtenção do resultado constitui seu maior inconveniente (Costa et al, 2007). 


\subsubsection{Métodos Sorológicos e Imunológicos}

A LV é caracterizada por hepato e esplenomegalia, hipergamaglobulinemia e presença de antígenos circulantes. Atualmente existem vários métodos disponíveis para o diagnóstico da leishmaniose visceral, porém os métodos sorológicos podem apresentar resultados conflitantes devido à presença de imunocomplexos presentes na amostra (Carvalho, 2010). Há vários procedimentos, porém os mais usados são:

- Método de Ensaio Imunoenzimático (ELISA)

Além de muito simples é econômico. Requer apenas 50 microlitros de sangue, colhido em papel de filtro sobre incisão na polpa digital. O sangue é eluído no laboratório. Sua sensibilidade fica acima de 98\%, mas a especificidade é de grupo, podendo dar resultado positivo na leishmaniose tegumentar e na tripanossomíase americana (Doença de Chagas), ainda que os títulos sejam muito mais altos na LV (Nascimento et al, 2005).

- Imunofluorescência Indireta (IFI)

Realizada em lâmina, usando-se como antígenos as formas promastigotas de cultura. Apresenta sensibilidade e especificidade superiores a 90\%. Na fase de estado agudo da LV é positiva, com títulos elevados, na totalidade dos casos. Dá reações cruzadas, mas em geral fracas, com tripanossomíase, malária, esquistossomíase, hanseníase, sífilis e algumas micoses sistêmicas, mas particularmente com a leishmaniose tegumentar. Seu inconveniente é a necessidade de microscópio de fluorescência para a leitura dos resultados. Por outro lado, os títulos mantêm-se elevados durante seis a nove meses após a cura (Goto et al, 2009).

- Teste de Aglutinação Direta (DAT)

É muito simples, barato e não requer habilidade ou equipamentos especiais. $\mathrm{O}$ antígeno é constituído de flagelados de cultura ou extrato de glicoproteínas de membrana dos promastigotas, que reagem com anticorpos séricos do paciente. Apresenta sensibilidade e especificidade elevadas (Tavares et al, 2005). 
- Reação Intradérmica de Montenegro (IDRM)

É também denominada teste da leishmanina, sendo este antígeno constituído por uma suspensão de promastigotas de cultura, lavadas e ressuspensas em salina com 5\% de fenol (concentração final de 10 milhões de promastigotas por mililitro). Injeta-se intradermicamente $0,1 \mathrm{ml}$ da suspensão. O resultado é lido 48 a 72 horas depois, registrando-se o diâmetro da reação. Ela indica contato com antígenos da leishmania e costuma ser negativa na fase ativa da doença; porém torna-se positiva depois de decorridos seis meses a três anos de cura. Reação cruzada pode ocorrer na hanseníase, tuberculose, e algumas infecções fúngicas. Seu uso é indicado em inquéritos epidemiológicos e em crianças com menos de 12 anos, quando é sugestiva de infecção (Nascimento et al, 2006).

- Reação em Cadeia de Polimerase (PCR)

O estudo do DNA sérico de Leishmania donovani está sendo feito em países como a Índia e comparado com o método de ELISA e os esfregaços de medula óssea. Os resultados coincidem, pelos três métodos, em cerca de metade dos casos; PCR e ELISA concordaram também em $28 \%$ de negativo, mas em $18 \%$ apenas PCR foi positivo. A reação de PCR mostra-se muito sensível para detectar casos incipientes, mas as condições para a sua realização limitam seu emprego na rotina médica (Goto, 2009).

\subsubsection{Teste Rápido Imunocromatográfico (TRALD; RICH)}

Trata-se de testes com base em imunocromatografia de papel, onde se utiliza o antígeno recombinante, fixado no papel. Este antígeno reconhece anticorpos específicos anti-Leishmania, do complexo donovani. Trata-se de um método sensível, específico e de rápida execução (5-10 mim) que pode ser usado nas condições de campo, porém, ainda se encontra em fase de avaliação (Assis et al, 2007).

\subsubsection{Métodos Presuntivos Inespecíficos}

São provas que decorrem de uma simples alteração da relação albumina/globulina, acentuada na LV, mas que se mostram também positivas em outras doenças infecciosas, como hanseníase, bouba, malária, esquistossomíase etc (Neves et al, 2005). 
A reação do formol-gel consiste na geleificação e opacificação do soro de pacientes com LV, quando a ele se adicionam algumas gotas de formol (duas gotas de formol do comércio para um mililitro de soro) (Nascimento et al, 2005).

Na reação de Brahmachari, ao soro contido em um tubo de hemólise se junta água, deixando-a escorrer pela parede do tudo para que não haja mistura. A reação é positiva quando há a produção de um anel de turvação na interface formada pelo soro do doente e a água (Rey et al, 2005).

\subsection{Tratamento e Prognóstico}

\subsubsection{Tratamento}

O regime terapêutico de primeira escolha para o tratamento da LV é baseado na utilização dos antimoniais pentavalentes, como o antimoniato de meglumina e o estibogluconato de sódio. Estes foram introduzidos pela primeira vez em 1945 e permanecem sendo utilizados como tratamentos eficazes. Porém, a necessidade de 28 dias de administração parenteral, a presença de reações adversas severas, a eficácia variável e o aparecimento de resistência são os fatores que limitam o uso destes medicamentos. No entanto, os medicamentos disponíveis para o tratamento são restritos, alguns como o desoxicolato de anfotericina $\mathrm{B}$, formulações lipídicas de anfotericina $\mathrm{B}$, miltefosina e paromomicina têm limitações em termos de toxicidade, eficácia variável, preços e esquemas de tratamento inconvenientes (Borborema, 2009).

O tratamento pode ser feito ambulatorialmente, embora pacientes graves ou instáveis devam ser hospitalizados. Especial atenção deve ser dada ao estado nutricional e a infecções bacterianas associadas (Frederic et al, 2005).

\subsubsection{Prognóstico}

O prognóstico não é bom em doentes não-tratados, havendo mortalidade na ordem de 75 a $85 \%$, entre as crianças, e de 90 a 95\%, entre os adultos. Essas taxas caíram consideravelmente graças aos recursos terapêuticos atuais. Conforme já foi referido, na Índia e na China costuma aparecer a leishmaníase dérmica pós-calazar, decorridos dois a 
10 anos do tratamento da doença. Este quadro responde bem à terapêutica antimonial, mas a recorrência não é rara e exige repetidos tratamentos (Ministério da Saúde, 2008).

A leishmaníase dérmica pós-calazar do Sudão e do Quênia pode apresentar-se durante ou depois da medicação, mas geralmente evolui espontaneamente para a cura dentro de poucos meses (Rei L et al, 2001).

\subsection{Profilaxia e Controle}

\subsubsection{Profilaxia}

A profilaxia da LV, desde a década de 1960, quando se estabeleceu o papel do cão como reservatório doméstico e de Lutzumya longipalpis como vetor, tem como base a tríade: diagnóstico e tratamento dos doentes; eliminação dos cães com sorologia positiva; e combate às formas adultas do inseto vetor (Ministério da Saúde, 2006).

Este delineamento foi adotado pelo Ministério da Saúde (MS) em forma de campanhas, e quando aplicado de maneira sistematizada e contínua foi eficaz em controlar a transmissão da doença, prevenindo o aparecimento de casos humanos (Elkhoury, 2009).

Para um programa de controle é fundamental o conhecimento das condições epidemiológicas de cada região através de levantamento da prevalência ou incidência da doença na população humana e canina, com base nas notificações realizadas pelos serviços de saúde, assim como através de inquéritos sorológicos específicos, estudos entomológicos, estudo dos possíveis reservatórios silvestres, reconhecimento geográfico, preparação de mapas de áreas de risco, elaboração de plano de ação e capacitação de pessoal (Ribeiro et al, 2001).

A tendência à urbanização da LV verificada nos últimos anos no Brasil está associada, dentre outros, aos seguintes fatores: processo migratório interregional e ruralurbano; ocupação desordenada do solo urbano; falta de saneamento ambiental associado à presença de animais domésticos (galinheiros, currais e chiqueiros) e detritos orgânicos e vegetação no peridomicílio; adaptação da Lutzumya longipalpis introduzida nesses novos ambientes; presença de fontes de infecção (cão ou próprio homem) associada à existência de indivíduos suscetíveis por predisposição imunológica, agravada por fatores nutricionais 
(hipovitaminoses e baixa ingestão de proteínas); e falta de informação para os profissionais de saúde e população, o que retarda o diagnóstico e o tratamento. (Romero et al, 2010).

Quanto à doença humana, três aspectos são importantes neste contexto. O primeiro, a associação da desnutrição como fator de risco para a infecção. Considerando que a prevalência da doença é maior na população menor que 10 anos, este aspecto indica que medidas adicionais devem ser tomadas, principalmente nos bolsões de pobreza onde a doença é endêmica. A identificação de indivíduos portadores do parasita, residentes em área endêmica, na ausência de sintomas, é uma questão relativamente nova, mas que pode influenciar as medidas de controle. A co-infecção com o vírus HIV, e o risco para contrair aids, para populações de área endêmica é preocupante, diante das alterações da relação parasita-hospedeiro, que podem estabelecer o homem como reservatório importante na transmissão da doença (Souza et al, 2007).

A ausência de educação da população para a saúde, o modelo de combate à transmissão da doença, isolado de outras ações de saúde pública, as relações afetivas de proprietários com os animais, o papel social do cão na segurança e companhia, dentre outros fatores, têm possibilitado comportamento pouco recomendável na sociedade. Assim proprietários que não concordam com a medida do sacrifício do cão, transportam seus animais de áreas endêmicas, por vezes, para regiões onde não existe doença, porém o transmissor está presente. Com o tempo, ações deste nível dificultam ou mesmo inviabilizam o controle da doença, contribuindo para o surgimento de novos focos e favorecendo ainda mais a sua expansão (Sabroza et al, 2005).

\subsubsection{Controle}

As estratégias de controle, até então utilizadas, estavam centradas e dirigidas verticalmente para o controle do reservatório canino (inquérito sorológico canino e eutanásia em cães soro reagentes), bem como para a aplicação de inseticidas, diagnóstico e tratamento adequado dos casos registrados. Entretanto, essas medidas, muitas vezes realizadas de forma isolada, não apresentaram efetividade para redução da incidência da doença, determinando a necessidade de reavaliação das ações propostas pelo Programa de Controle da Leishmaniose Visceral (PCLV) (Ministério da Saúde, 2008). 
O controle da LV exige um conhecimento preliminar das condições epidemiológicas, em cada região, para que se possa elaborar um plano racional, objetivo e ajustado às peculiaridades de cada ecossistema, bem como aos recursos disponíveis (Camargo-Neves et al , 2001).

Segundo Rey, 2005, a coleta de dados epidemiológicos, antes de se iniciarem as operações de controle (ou, melhor, antes de planejá-las), é indispensável para a avaliação dos resultados. Portanto, devem ser feitos:

- Levantamentos para conhecer as áreas endêmicas e a prevalência (ou incidência) da doença na população humana da cada lugar, tomando como base as notificações feitas pelos médicos, hospitais e serviços de saúde, bem como os inquéritos sorológicos realizados especialmente para isso;

- Inquéritos sorológicos em cães, para estimar a prevalência do calazar canino e avaliar sua importância como fonte de infecção;

- Estudo da fauna flebotomínica da região, para conhecer a distribuição e a frequência da espécie vetora, dentro e fora das casas, nas diversas épocas do ano e sob diferentes condições;

- Estudos sobre reservatórios silvestres do parasita que eventualmente se encontrem na área, para completar o quadro epidemiológico e recomendar medidas especificas de controle dessas fontes de infecção, quando for o caso;

- Preparação de mapas regionais detalhados e reconhecimento geográfico da área a trabalhar;

- Estabelecimento de um plano de controle que defina os objetivos precisos, a estratégia adotada, os métodos de ação e os recursos necessários (econômicos, logísticos e de pessoal). Ele deve compreender os métodos de avaliação dos resultados do controle em curto e longo prazos. Este plano deverá ser aprovado e apoiado pelas autoridades competentes e por aqueles responsáveis em assegurar seu financiamento;

- Recrutamento e formação adequada do pessoal que participará dos trabalhos programados para o controle da endemia;

- Combate aos flebotomíneos.

Para impedir o aparecimento de novos casos, é preciso interromper a transmissão com a aplicação de inseticidas. Os flebotomíneos são suscetíveis à ação dos 
inseticidas de efeito residual, como os piretróides e outros inseticidas, em emulsão ou suspensão e dos abrigos de animais domésticos (estrebarias, currais, chiqueiros e galinheiros), onde os insetos se reúnem em grande número. A quantidade de inseticidas por metro quadrado deve ser de ordem de dois gramas. Desse modo, as fêmeas são destruídas em proporções elevadas, desfazendo rapidamente a população de insetos. Mas quando estes têm hábitos exófilos, ou são estritamente silvestres, seu controle torna-se difícil. Daí ser necessário desenvolver, ao mesmo tempo, um trabalho de extinção das fontes de infecção existentes na região (Missawa et al, 2009).

A possibilidade de aplicação de uma vacina eficaz contra a leishmaniose canina deverá constituir eficiente meio de controle, tanto da doença humana como da doença canina. Tal procedimento deve ser técnica e economicamente possível, uma vez que poderia se ministrado simultaneamente com vacina anti-rábica, cujo programa no Brasil tem sido bem-sucedido (Marzochi et al, 2001).

Existe no Brasil uma vacina contra a LV canina, constituída do ligante fucosemanose de Leishmania donovani registrada no Ministério da Agricultura, Pecuária e Abastecimento sob o nome de Leishmuni. Os testes realizados com esta vacina mostraram resultados com qualidade que lhe permitiu o registro. Entretanto, seu uso, no primeiro momento, deverá ser restrito a clínicas veterinárias, aguardando análise do Ministério da Saúde sobre seu impacto no controle da LV endêmica (Melo, 2004).

Estudos de novas vacinas, constituídas de antígenos recombinantes e vacinas de DNA, continuam sendo realizados em vários núcleos de pesquisa, que poderão em futuro próximo ser disponibilizadas para uso animal. Ao lado de qualquer medida profilática deve haver controle rigoroso de cães vadios, o que contribuiria para a redução de sua população errante e de possíveis fontes de infecção (Neves et al, 2005).

É importante reafirmar que ações de controle voltadas para o tratamento humano, identificação e sacrifício de cães soropositivos e controle da população de flebotomíneos devem ser aplicadas voltadas para as condições locais de transmissão e em conjunto para que sejam eficazes. Entretanto, devem integrar outras ações de produção de saúde, acompanhadas de sólida vigilância epidemiológica e de processo de educação para a saúde e o bem-estar social (Gontijo et al, 2004). 


\section{MATERIAL E MÉTODOS}

Realizou-se um estudo descritivo de corte transversal para avaliar o quadro da Leishmaniose Visceral Humana no município de Araguaína (TO) no período de janeiro de 2007 a agosto de 2010. Adicionalmente, foram realizados ensaios para comparar as abordagens diagnósticas sorológicas para o diagnóstico da doença.

\section{1 Área de Estudo}

Em 2.010, de acordo com o último censo populacional, a população do município de Araguaína foi de 150.520 habitantes, sendo um dos mais populosos do estado. Está localizado na região norte do estado do Tocantins a uma latitude $07^{\circ} 11^{\prime} 28^{\prime \prime}$ sul e a uma longitude 48 12 '26" oeste. Possui uma área de 4.000,4 $\mathrm{km}^{2}$ e densidade demográfica de $29,91 \mathrm{hab} / \mathrm{km}^{2}$ e altitude de $227 \mathrm{~m}$. Apresenta relevo bastante variado, destacando-se o planalto sem a presença de grandes elevações. O município apresenta clima tropical úmido, e temperatura quente durante todo ano, variando de máxima de $32^{\circ} \mathrm{C}$, mínima de $20^{\circ} \mathrm{C}$. O município possui 109 bairros e 42 estabelecimentos de saúde do SUS. (IBGE, 2010).

\subsection{Aspectos Éticos}

O projeto foi submetido e aprovado pelo Comitê de Ética em Pesquisa da Fundação de Medicina Tropical do Estado do Tocantins, sob o n ${ }^{\circ}$ 79/10 (ANEXO). Foram feitas solicitações, por meio de ofício, aos diretores do Centro de Controle de Zoonoses (CCZ) e do Laboratório de Saúde Pública (LSP) de Araguaína, para permitir o acesso aos dados epidemiológicos e às amostras de soros, respectivamente.

\subsection{Coleta de Dados}

A fonte de dados para o estudo epidemiológico foi constituída pelas fichas de investigação do SINAN do CCZ, no período de 2007 a agosto de 2010. 


\subsection{Amostra Sorológica}

A amostra utilizada para o ensaio laboratorial foi composta por 391 soros humanos que seriam encaminhados para descarte ou estocados na soroteca do Laboratório de Saúde Pública (LSP) de Araguaína, laboratório estadual de médio porte responsável pelo diagnóstico laboratorial de LV de Araguaína e municípios circunvizinhos. Os soros foram mantidos de forma incógnita, sendo anotado, apenas, idade, sexo e suspeita clínica dos pacientes, sendo divididos em três grupos:

4.4.1 Amostra de pacientes portadores de LVH

Este grupo foi constituído de 100 soros positivos para a RIFI nas diluições 1:40 e 1:80. A coleta foi realizada no período de 25/08/2009 a 15/03/2010.

\subsubsection{Amostra de pacientes suspeitos de LVH}

A coleta foi realizada no período de 30/12/2009 a 25/02/2010, totalizando 100 soros negativos para a RIFI, porém os pacientes apresentavam clínica da doença.

\subsubsection{Amostra de pacientes não-suspeitos de LVH}

Este grupo foi constituído de 191 soros de pacientes que não foram testados na RIFI pelo fato dos pacientes não apresentarem clínica para a LVH. A coleta foi realizada no período de 01/02/2010 a 16/08/2010.

\subsection{Ensaios Sorológicos}

Os soros de pacientes suspeitos e não suspeitos de LVH foram recebidos no no Laboratório de Protozoologia do Instituto de Medicina Tropical (IMT) da Faculdade de Medicina da Universidade de São Paulo (FMUSP) em 22 de agosto de 2010, com a reação de Reação de Imunofluorescência Indireta (RIFI) já realizada previamente pelo LSP, laboratório clínico de referência. 
Os soros foram avaliados em duplicatas, no IMT/FMUSP, por método imunoenzimático ELISA convencional (ELISAH- in house) e ELISA dissociativo (ELISAD), esta última, uma nova técnica que promove a dissociação de imunocomplexos.

\subsubsection{Reação de Imunofluorescência Indireta (RIFI)}

Os soros foram diluídos a 1/80 e 1/160 e submetidas ao kit BioManguinhos de Imunofluorescência Indireta para Leishmaniose Visceral Humana (fornecido pelo Ministério da Saúde do Brasil e executado por pessoal previamente treinado) no LSP de Araguaína. O resultado foi definido como negativo (não-reagente), positivo (reagente) 1/80 ou positivo 1/160. Este kit utiliza formas promastigotas de Leishmania major como antígeno aderido à lâmina.

\subsubsection{ELISA Convencional (ELISAH) e ELISA Dissociativo (ELISAD)}

O ensaio ELISAH foi desenvolvido de acordo com a metodologia descrita na literatura (Venkatesan e Walklin, 1993). O ELISAD foi efetuado a partir de uma modificação do teste de ELISAH com mudança brusca de pH (Carvalho et al, 2010). Ambos os ensaios foram realizados em duplicatas.

\subsubsection{Parasitas utilizados}

O antígeno foi obtido a partir da manutenção de culturas de Leishmania chagasi, após o crescimento das formas promastigotas do parasita. A cultura foi centrifugada a $2000 \mathrm{RPM}$ por $10 \mathrm{~min}$. e o sobrenadante, descartado. O pellet é centrifugado novamente em microcentrífuga a 2.000 RPM por 10 min.. O sobrenadante foi desprezado e o pellet armazenado a $-80^{\circ} \mathrm{C}$.

A ressuspensão do pellet de Leishmania chagasi congelado foi feita em solução tampão de amostra (TRIS-HCL 0,05M pH 6,0, uréia 4M, EDTA 5M, PMSF 0,5 $\mathrm{M}, \mathrm{KCL} 0,1 \mathrm{M}$ e SDS 0,5\%). Em seguida, foi aquecido por 15 minutos a $65^{\circ} \mathrm{C}$, centrifugado a 10.000 RPM por 5 minutos e as proteínas foram dosadas pelo método de Bradford. 


\subsubsection{Técnica Empregada}

As placas foram previamente sensibilizadas com $100 \mu$ l de antígeno de $L$. chagasi a uma concentração de $10 \mu \mathrm{g} / \mathrm{ml}$ por poço, permanecendo em repouso por $18 \mathrm{~h}$, em $4^{\circ} \mathrm{C}$. Em seguida, fez-se o bloqueio com tampão PBSTL (Phosphate buffered saline + tween + leite desnatado), por $1 \mathrm{~h}$ à $37^{\circ} \mathrm{C}$. As amostras foram diluídas a 1:200 com tampão PBS (Phosphate buffered saline) e distribuídas na quantidade de 100 $\mu 1 /$ poço. Logo após, adicionou-se $25 \mu 1$ de solução de glicina $0,1 \mathrm{M}$ pH 2,5 para o método de ELISAD e $25 \mu 1$ de PBS para o método de ELISAH, para a equivalência nas diluições. As placas foram agitadas por 5 minutos. Adicionou-se $25 \mu 1$ de TRIS (tris-hidroximetilaminometano) pH 8,5 no método de ELISAD e $25 \mu 1$ de PBS no ELISAH. As placas foram incubadas a $37^{\circ} \mathrm{C}$ por 1h. e em seguidas lavadas por 5 vezes com tampão PBSTL. O conjugado foi preparado com anticorpo Anti-IgG Humana na diluição 1:20.000 e distribuído 100 $\mu 1 /$ poço. As placas foram novamente incubadas a $37^{\circ} \mathrm{C}$ por $1 \mathrm{~h}$. e em seguida, lavadas por 5 vezes com tampão PBSTL. A reação foi revelada com a distribuição de $100 \mu \mathrm{L}$ de solução de OPD (ortofenilenodiamina 0,5g p/ $20 \mathrm{ml}$ de água MILIQ + $10 \mu \mathrm{l}$ de $\mathrm{H}_{2} \mathrm{O}_{2}(30 \%)$ por poço. As placas permaneceram ao abrigo da luz (câmara escura) por 30 minutos. Fez-se o bloqueio da reação com $50 \mu 1$ de HCL (ácido clorídrico)/poço. A leitura foi efetuada em leitora de ELISA Labsystems Multiskan MS, utilizando filtro 492nm.

\subsection{Análises Estatísticas}

Para avaliar a reprodutibilidade dos ensaios em amostras, foi utilizada a regressão linear como modo de avaliação. Os dados epidemiológicos foram processados no programa EXCEL, utilizando frequiências absoluta e relativa. 


\section{RESULTADOS}

\subsection{Levantamento Epidemiológico}

Na distribuição dos 964 casos confirmados de LV no estado do Tocantins, no período de janeiro de 2.007 a agosto de 2.010, por municípios, Araguaína representou $79,8 \%$ no total dos casos. Houve um aumento em 2.008, com 283 casos confirmados (TAB. 1).

TABELA 1 Distribuição dos casos de LV confirmados por municípios da região Norte do Estado do Tocantins segundo o ano de notificação

\begin{tabular}{lrrrrrrr}
\hline \multicolumn{1}{c}{ Municípios } & $\begin{array}{c}\text { Pop. estimada } \\
\text { para 2010 }\end{array}$ & $\mathbf{2 0 0 7}$ & $\mathbf{2 0 0 8}$ & $\mathbf{2 0 0 9}$ & $\mathbf{2 0 1 0}$ & Total & \\
\hline & & FA & FA & FA & FA & FA & FR(\%) \\
Aguianópolis & 5.158 & 0 & 4 & 3 & 1 & 8 & 0,8 \\
Ananás & 9.873 & 3 & 2 & 2 & 0 & 7 & 0,7 \\
Aragominas & 5.882 & 2 & 2 & 0 & 1 & 5 & 0,5 \\
Araguaína & 150.520 & 255 & 283 & 163 & 68 & 769 & 79,8 \\
Araguatins & 31.324 & 4 & 6 & 6 & 2 & 18 & 1,9 \\
Araguanã & 5.030 & 8 & 3 & 0 & 0 & 11 & 1,1 \\
Arapoema & 6.742 & 0 & 0 & 2 & 0 & 2 & 0,2 \\
Babaçulândia & 10.446 & 6 & 6 & 0 & 0 & 12 & 1,2 \\
Buriti do TO & 9.770 & 1 & 0 & 2 & 0 & 3 & 0,3 \\
Colinas do TO & 30.879 & 0 & 1 & 4 & 9 & 14 & 1,5 \\
Colméia & 8.607 & 0 & 0 & 4 & 3 & 7 & 0,7 \\
Conceição do TO & 4.182 & 0 & 0 & 2 & 0 & 2 & 0,2 \\
Couto Magalhães & 5.009 & 3 & 2 & 0 & 0 & 5 & 0,5 \\
Guaraí & 23.212 & 1 & 3 & 2 & 3 & 9 & 0,9 \\
Juarina & 2.231 & 1 & 0 & 3 & 4 & 8 & 0,8 \\
Nova Olinda & 10.686 & 3 & 4 & 5 & 5 & 17 & 1,8 \\
Santa Fé do Araguaia & 6.599 & 5 & 0 & 2 & 0 & 7 & 0,7 \\
Tocantinópolis & 22.608 & 4 & 8 & 3 & 3 & 18 & 1,9 \\
Wanderlândia & 10.878 & 9 & 4 & 2 & 0 & 15 & 1,6 \\
Xambioá & 11.484 & 2 & 2 & 2 & 0 & 6 & 0,6 \\
Total & & 310 & 331 & 217 & 106 & 964 & $100 \%$ \\
\hline Fonte: CCZ, SINAN NET & & & & & & & $8 \%$
\end{tabular}

Fonte: CCZ, SINAN NET

Legenda: LV: Leishmaniose visceral; FA: Frequência absoluta; FR (\%): Frequência relativa; POP: população 
No período em estudo, Araguaína apresentou 882 casos de leishmanioses, sendo que destes, $769(87,2 \%)$ foram de LVH e 113 (12,8\%) foram de LTA (TAB. 2 e FIG.1).

TABELA 2 - Frequência de casos confirmados de leishmanioses em Araguaína segundo o ano de notificação

\begin{tabular}{|c|c|c|c|c|c|}
\hline \multirow[t]{2}{*}{ Ano } & \multicolumn{2}{|c|}{$\mathbf{L V}$} & \multicolumn{2}{|c|}{ LTA } & \multirow{2}{*}{$\begin{array}{l}\text { Total } \\
\text { FA } \\
\end{array}$} \\
\hline & FA & $\operatorname{FR}(\%)$ & FA & $\operatorname{FR}(\%)$ & \\
\hline 2007 & 255 & 91 & 25 & 9 & 280 \\
\hline 2008 & 283 & 90,1 & 31 & 9,9 & 314 \\
\hline 2009 & 163 & 78 & 46 & 22 & 209 \\
\hline 2010 & 68 & 86 & 11 & 14 & 79 \\
\hline Total & 769 & 87,2 & 113 & 12,8 & 882 \\
\hline
\end{tabular}

Fonte: CCZ, SINAN NET

Legenda: LV: Leishmaniose visceral; LTA: Leishmaniose tegumentar americana; FA: Frequência absoluta; FR (\%): Frequência relativa

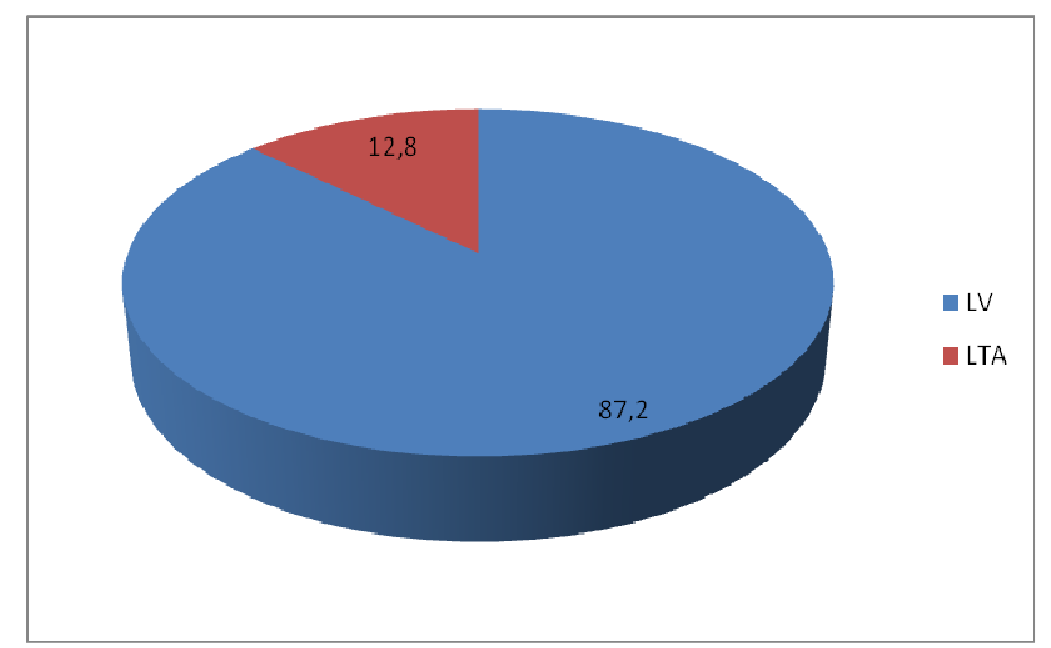

FIGURA 1 - Frequência de casos confirmados de leishmanioses em Araguaína no período de jan/2007 a ago/2010

A incidência da doença nos anos estudados foi de 220,28 em 2007; 244,47 em 2008; 136,24 em 2009; e 113,66 de janeiro a agosto de 2010 (TAB.3). 
TABELA 3 - Incidência da LV no município de Araguaína no período de janeiro de 2007 a agosto de 2010

\begin{tabular}{lcl}
\hline & $\mathbf{N}^{\mathbf{0}}$ de casos confirmados & Incidência* \\
2007 & 255 & 220,28 \\
2008 & 283 & 244,47 \\
2009 & 163 & 136,24 \\
2010 (jan a ago) & 68 & 113,66 \\
Total & 769 & \\
\hline
\end{tabular}

Fonte: CCZ, SINAN NET

Legenda: LV: Leishmaniose visceral; *Por 100.000 habitantes

Dos 769 casos de LV, 98,7\% foram casos novos; 0,8\%, recidiva; e 0,1\%, transferido (TAB.4).

TABELA 4 - Distribuição dos casos de LV confirmados por tipo de entrada segundo o ano de notificação

\begin{tabular}{llllllr} 
Tipo de entrada & $\mathbf{2 0 0 7}$ & $\mathbf{2 0 0 8}$ & $\mathbf{2 0 0 9}$ & $\mathbf{2 0 1 0}$ & \multicolumn{2}{l}{ Total } \\
\hline & FA & FA & FA & FA & FA & FR (\%) \\
Ign/Branco & 0 & 1 & 2 & 0 & 3 & 0,4 \\
Caso novo & 253 & 277 & 161 & 68 & 759 & 98,7 \\
Recidiva & 2 & 4 & 0 & 0 & 6 & 0,8 \\
Transferência & 0 & 1 & 0 & 0 & 1 & 0,1 \\
Total & 255 & 283 & 163 & 68 & 769 & $100 \%$ \\
\hline
\end{tabular}

Fonte: CCZ, SINAN NET

Legenda: LV: Leishmaniose visceral; FA: Frequência absoluta; FR (\%): Frequência relativa; Ign: ignorado.

Com relação à distribuição por sexo, o estudo mostrou um predomínio do sexo masculino de 57,8\% em todos os anos analisados (TAB. 5).

TABELA 5 - Distribuição dos casos de LV confirmados em Araguaína por sexo segundo o ano de notificação

\begin{tabular}{|c|c|c|c|c|c|c|}
\hline Sexo & 2007 & 2008 & 2009 & 2010 & Total & \\
\hline & FA & FA & FA & FA & FA & $\begin{array}{l}\text { FR } \\
(\%)\end{array}$ \\
\hline Masculino & 152 & 153 & 98 & 41 & 444 & 57,8 \\
\hline Feminino & 103 & 130 & 65 & 27 & 325 & 42,2 \\
\hline Total & 255 & 283 & 163 & 68 & 769 & $100 \%$ \\
\hline
\end{tabular}

Legenda: LV: Leishmaniose visceral; FA: Frequência absoluta; FR (\%): Frequência relativa 
Dos 769 casos notificados no período em estudo, 14,4\% foram em menores de 1 ano; 37,4\% na faixa etária de 1 a 4 anos; $13 \%$ de 5 a 9 anos; 6,5\% de 10 a 14 anos. Ressalta-se, também, 12,6\% dos casos na faixa etária entre 20 a 34 anos (TAB.6 e FIG.2).

TABELA 6 - Distribuição dos casos de LV confirmados por faixa etária segundo o ano de notificação

\begin{tabular}{lrrrrrr}
\hline Faixa Etária & $\mathbf{2 0 0 7}$ & $\mathbf{2 0 0 8}$ & $\mathbf{2 0 0 9}$ & $\mathbf{2 0 1 0}$ & \multicolumn{2}{c}{ Total } \\
\hline & FA & FA & FA & FA & FA & FR (\%) \\
\hline$<1$ ano & 32 & 37 & 26 & 16 & 111 & 14,4 \\
1 a 4 & 95 & 108 & 57 & 27 & 287 & 37,4 \\
5 a 9 & 34 & 35 & 24 & 7 & 100 & 13 \\
10 a 14 & 21 & 18 & 11 & 0 & 50 & 6,5 \\
15 a 19 & 13 & 17 & 12 & 3 & 45 & 5,8 \\
20 a 34 & 36 & 37 & 17 & 7 & 97 & 12,6 \\
35 a 49 & 14 & 17 & 10 & 1 & 42 & 5,5 \\
50 a 64 & 5 & 10 & 4 & 5 & 24 & 3,1 \\
65 a 79 & 5 & 3 & 1 & 1 & 10 & 1,3 \\
80 e + & 0 & 1 & 1 & 1 & 3 & 0,4 \\
Total & 255 & 283 & 163 & 68 & 769 & $100 \%$ \\
\hline Fo & & & & & &
\end{tabular}

Fonte: CCZ, SINAN NET

Legenda: LV: Leishmaniose visceral; FA: Frequência absoluta; FR (\%): Frequência relativa

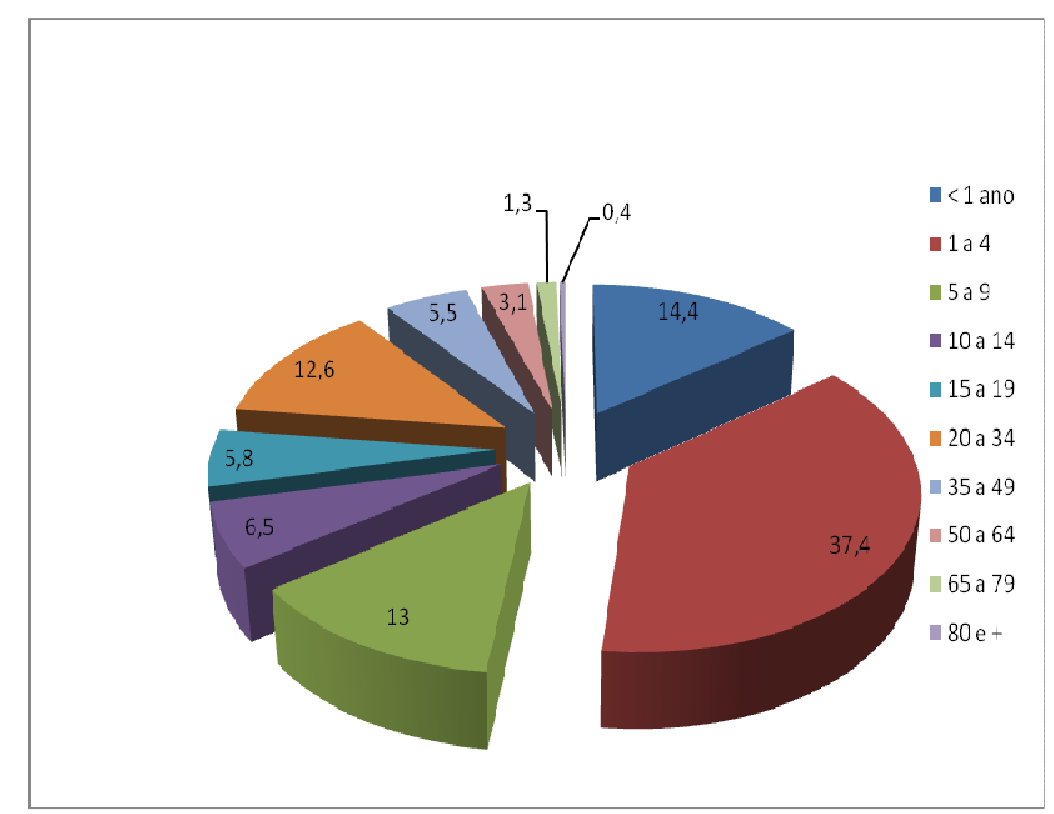

FIGURA 2 - Distribuição dos casos de LV confirmados por faixa etária no período de jan/2007 a ago/2010 
$\mathrm{Na}$ distribuição por zona de residência, no período em estudo, foram notificados $759(98,5 \%)$ casos na zona urbana e $10(1,4 \%)$ na zona rural (TAB. 7$)$.

TABELA 7 - Distribuição dos casos de LV confirmados por zona de residência segundo o ano de notificação

\begin{tabular}{lllllll}
\hline $\begin{array}{l}\text { Zona de } \\
\text { residência }\end{array}$ & $\mathbf{2 0 0 7}$ & $\mathbf{2 0 0 8}$ & $\mathbf{2 0 0 9}$ & $\mathbf{2 0 1 0}$ & Total & \\
\hline & FA & FA & FA & FA & FA & FR (\%) \\
Rural & 2 & 2 & 3 & 3 & 10 & 1,4 \\
Urbana & 253 & 281 & 159 & 66 & 759 & 98,6 \\
Total & 255 & 283 & 162 & 69 & 769 & $100 \%$ \\
\hline
\end{tabular}

Fonte: CCZ, SINAN NET

Legenda: LV: Leishmaniose visceral; FA: Frequência absoluta; FR (\%): Frequência relativa

Com relação à distribuição dos casos confirmados de LV por bairros de residência, os que apresentaram maior número de casos foram Nova Araguaína, 12\%; Araguaína Sul, 10,9\%; São João, 6,6\%; e Maracanã, com 6,4\% dos casos confirmados (TAB. 8 e FIG.3).

TABELA 8 - Distribuição dos casos de LV confirmados por bairros segundo o ano de notificação

\begin{tabular}{lrrrrrr} 
Bairro Residencial & $\mathbf{2 0 0 7}$ & $\mathbf{2 0 0 8}$ & $\mathbf{2 0 0 9}$ & $\mathbf{2 0 1 0}$ & Total & FR(\%) \\
\hline Araguaína Sul & 34 & 29 & 13 & 8 & 84 & 10,9 \\
Cimba & 2 & & 1 & & 3 & 0,4 \\
De Fátima & 5 & 4 & 3 & & 12 & 1,6 \\
Eldorado & 1 & 5 & & & 6 & 0,8 \\
JK & 1 & 5 & 2 & & 8 & 1,0 \\
Barros & 9 & 6 & 2 & 2 & 19 & 2,5 \\
Bela Vista & & 1 & 2 & & 3 & 0,4 \\
Centro & 4 & 5 & 4 & 1 & 14 & 1,8 \\
Céu Azul & 8 & 3 & 1 & 3 & 15 & 2,0 \\
Jardim das Flores & 2 & & 1 & 2 & 5 & 0,7 \\
Jardim Pedra Alta & 1 & 2 & & & 3 & 0,4 \\
Jardim das Palmeiras & 2 & & 1 & & 3 & 0,4 \\
Jardim Paulista & 3 & 3 & 2 & & 8 & 1,0 \\
Morada do Sol & 3 & 7 & 5 & 1 & 16 & 2,1 \\
Maracanã & 10 & 17 & 16 & 6 & 49 & 6,4 \\
Nova Araguaína & 32 & 33 & 20 & 7 & 92 & 12,0 \\
Parque Bom Viver & 1 & 4 & 2 & 2 & 9 & 1,2
\end{tabular}




\begin{tabular}{|c|c|c|c|c|c|c|}
\hline Parque Sonhos Dourados & 2 & 4 & 1 & & 7 & 0,9 \\
\hline Residencial Patrocínio & 4 & 1 & & & 5 & 0,7 \\
\hline Setor Brasil & 10 & 4 & 3 & & 17 & 2,2 \\
\hline Setor Coimbra & 3 & 2 & 1 & 1 & 7 & 0,9 \\
\hline Setor Couto & 2 & & 3 & & 5 & 0,7 \\
\hline Setor Helena & 2 & 1 & 2 & & 5 & 0,7 \\
\hline Setor Itapuã & 2 & 5 & & & 7 & 0,9 \\
\hline Setor Santa Luzia & 3 & 2 & 2 & & 7 & 0,9 \\
\hline Setor São Miguel & 4 & 4 & 3 & & 11 & 1,4 \\
\hline Noroeste & 6 & & 2 & & 8 & 1,0 \\
\hline Setor Oeste & & 4 & 2 & 1 & 7 & 0,9 \\
\hline Setor Planalto & 2 & 2 & 3 & 1 & 8 & 1,0 \\
\hline Setor Raizal & 3 & 14 & 5 & 3 & 25 & 3,3 \\
\hline Setor Santa Tereza & 4 & 5 & 2 & 3 & 14 & 1,8 \\
\hline Setor Tocantins & 1 & 7 & 1 & & 9 & 1,2 \\
\hline Setor Urbano & 3 & 4 & 5 & & 12 & 1,6 \\
\hline Setor Tereza Hilário & & 1 & 5 & & 6 & 0,8 \\
\hline Setor Tiúba & 2 & 1 & & & 3 & 0,4 \\
\hline Setor Universitário & 9 & 10 & 4 & 5 & 28 & 3,6 \\
\hline Vila Couto Magalhães & 1 & 2 & & & 3 & 0,4 \\
\hline Vila Goiás & & 9 & 6 & 2 & 17 & 2,2 \\
\hline Vila Norte & 8 & 9 & & & 17 & 2,2 \\
\hline Vila Ribeiro & & 3 & 5 & 1 & 9 & 1,2 \\
\hline Vila Santiago & 3 & 1 & & & 4 & 0,5 \\
\hline Jardim das Mangueiras & 1 & 3 & 1 & & 5 & 0,7 \\
\hline Setor Palmas & 4 & 2 & 1 & 2 & 9 & 1,2 \\
\hline Setor Alto Bonito & & 4 & & & 4 & 0,5 \\
\hline Setor Monte Sinai & 4 & 5 & 3 & 1 & 13 & 1,7 \\
\hline Vila Santa Rita & & 5 & & 2 & 7 & 0,9 \\
\hline Setor Xixebal & 9 & 6 & 2 & 1 & 18 & 2,3 \\
\hline Zona Rural & 2 & 2 & 3 & 3 & 10 & 1,4 \\
\hline Imaculada Conceição & 3 & 2 & & 1 & 6 & 0,8 \\
\hline Dom Orione & & 5 & & 1 & 6 & 0,8 \\
\hline Neblina & 1 & 1 & 3 & & 5 & 0,7 \\
\hline São João & 23 & 19 & 6 & 3 & 51 & 6,6 \\
\hline Outros bairros & 7 & 5 & 10 & 4 & 26 & 3,3 \\
\hline Total & 255 & 284 & 163 & 67 & 769 & $100 \%$ \\
\hline
\end{tabular}

Fonte: CCZ, SINAN NET

Legenda: LV: Leishmaniose visceral; FR(\%): Frequência relativa 


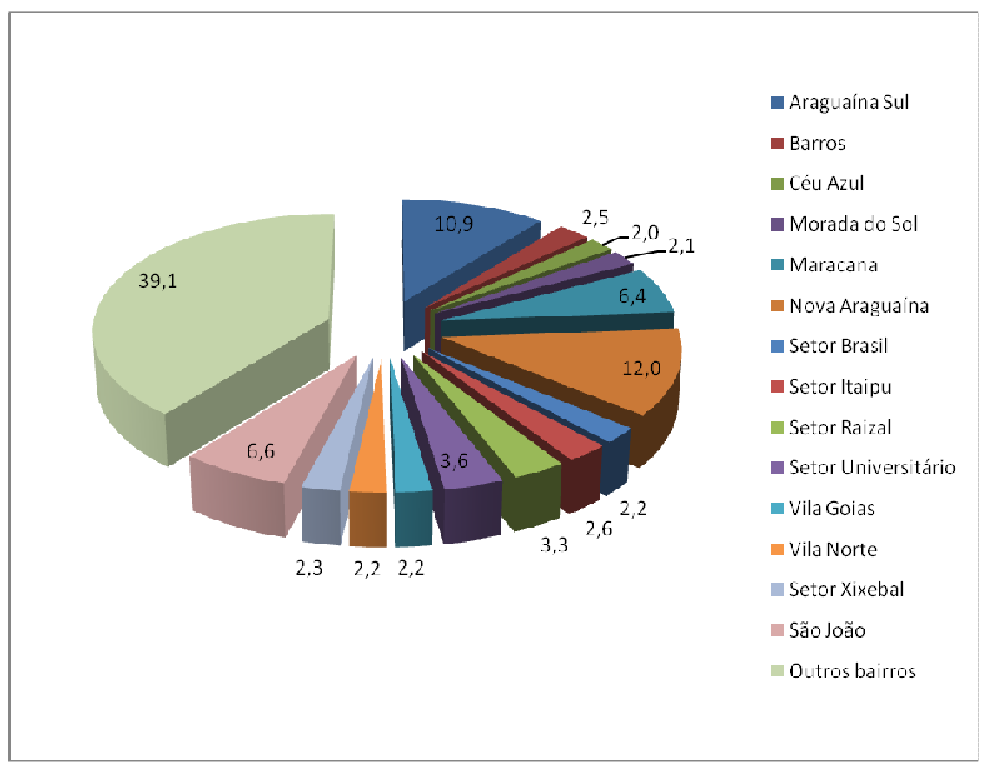

FIGURA 3 - Distribuição dos casos de LV confirmados por bairros no período de jan/2007 a ago/2010

As manifestações clínicas mais frequentes foram febre (97\%), fraqueza (91,5\%), palidez $(75,4 \%)$, emagrecimento (75\%), aumento de baço (67\%) e fígado $(63 \%)$ (TABELA 9).

TABELA 9 - Distribuições das manifestações clínicas nos casos de LV confirmados segundo o ano de notificação

\begin{tabular}{lrrrrrr} 
Ano de notificação & $\mathbf{2 0 0 7}$ & $\mathbf{2 0 0 8}$ & $\mathbf{2 0 0 9}$ & $\mathbf{2 0 1 0}$ & & Total \\
\hline $\begin{array}{lrrrcr}\text { Manifestações } \\
\text { Clínicas }\end{array}$ & FA & FA & FA & FA & FA & FR (\%) \\
\hline & & & & & & \\
Aumento do fígado & 177 & 175 & 91 & 41 & 484 & 63 \\
Aumento do baço & 163 & 196 & 108 & 46 & 513 & 67 \\
Emagrecimento & 213 & 194 & 117 & 54 & 578 & 75 \\
Edema & 5 & 17 & 19 & 10 & 51 & 6,6 \\
Febre & 250 & 279 & 153 & 65 & 747 & 97 \\
Fraqueza & 239 & 255 & 148 & 62 & 704 & 91,5 \\
Palidez & 150 & 230 & 141 & 59 & 580 & 75,4 \\
Tosse e/ou diarréia & 156 & 148 & 88 & 53 & 445 & 57,8 \\
Icterícia & 2 & 14 & 23 & 14 & 53 & 6,9 \\
Outras & & & & & & \\
manifestações & 31 & 55 & 40 & 7 & 133 & 17,3 \\
Total & 255 & 283 & 163 & 68 & & 769 \\
\hline Fonte: CCZ SINAN NET & & & & & &
\end{tabular}


Dos 769 casos de LV, 765 (99,5\%) tiveram como confirmação o diagnóstico laboratorial e apenas $4(0,5 \%)$ a confirmação foi feita pelo diagnóstico clinicoepidemiológico (TAB. 10).

TABELA 10 - Critério de confirmação dos casos de LV confirmados segundo o ano de notificação

\begin{tabular}{lrrrrrr}
\hline $\begin{array}{l}\text { Critério de } \\
\text { confirmação }\end{array}$ & $\mathbf{2 0 0 7}$ & $\mathbf{2 0 0 8}$ & $\mathbf{2 0 0 9}$ & $\mathbf{2 0 1 0}$ & & Total \\
\hline & FA & FA & FA & FA & FA & FR (\%) \\
Laboratorial & 255 & 281 & 162 & 67 & 765 & 99,5 \\
& & & & & & \\
Clínico-epidem. & 0 & 2 & 1 & 1 & 4 & 0,5 \\
Total & 255 & 283 & 163 & 68 & 769 & $100 \%$ \\
\hline $\begin{array}{l}\text { Fonte: CCZ, SINAN NET } \\
\text { Legenda: LV: Leishmaniose visceral; FA: Frequência absoluta; FR(\%): Frequência relativa }\end{array}$
\end{tabular}

Dos métodos de diagnóstico laboratorial, o mais utilizado foi a Reação de Imunofluorescência Indireta (RIFI) para Leishmaniose Humana, em 97,8\% dos casos (TAB. 11 e FIG.4).

TABELA 11 - Diagnóstico laboratorial dos casos de LV confirmados segundo o ano de notificação

\begin{tabular}{|c|c|c|c|c|c|c|}
\hline Diagnóstico & 2007 & 2008 & 2009 & 2010 & \multicolumn{2}{|c|}{ Total } \\
\hline & FA & FA & FA & FA & FA & $\operatorname{FR}(\%)$ \\
\hline RIFI & 254 & 277 & 159 & 62 & 752 & 97,8 \\
\hline Parasitológico & 1 & 5 & 3 & 5 & 14 & 1,8 \\
\hline Outro diagnóstico imunológico & 0 & 1 & 1 & 1 & 3 & 0,4 \\
\hline Total & 255 & 283 & 163 & 68 & 769 & $100 \%$ \\
\hline
\end{tabular}

Fonte: CCZ, SINAN NET

Legenda: LV: Leishmaniose visceral; FA: Frequência absoluta; FR (\%): Frequência relativa; RIFI: Reação de imunofluorescência indireta 


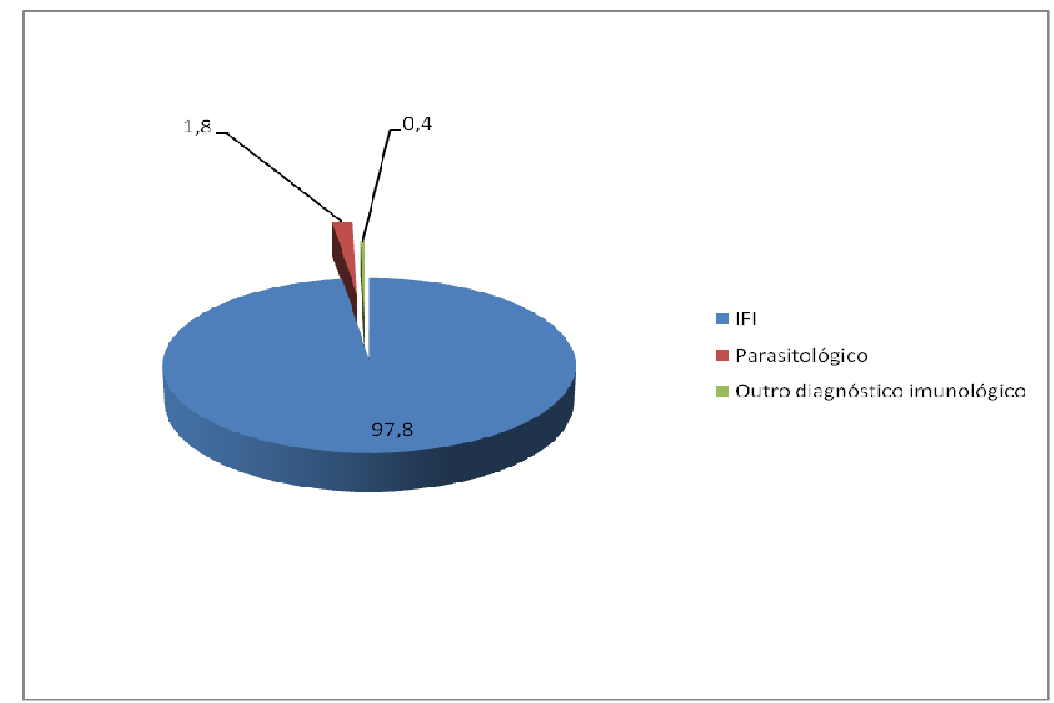

FIGURA 4 - Distribuição dos casos de LV confirmados por diagnóstico laboratorial período de 2007 a ago/2010

Com relação ao tratamento, 90,5\% dos pacientes receberam como droga inicial o antimônio pentavalente; 7,4\%, anfotericina B; e 1,5\%, Anfotericina B lipossomal (TAB. 12).

TABELA 12 - Droga inicial nos casos de LV confirmados segundo o ano de notificação

\begin{tabular}{|c|c|c|c|c|c|c|}
\hline Droga inicial & 2007 & 2008 & 2009 & 2010 & & Total \\
\hline & FA & FA & FA & FA & FA & FR (\%) \\
\hline Ign/Branco & 0 & 2 & 1 & 2 & 5 & 0,6 \\
\hline $\begin{array}{l}\text { Antimônio } \\
\text { pentavalente }\end{array}$ & 250 & 256 & 145 & 45 & 696 & 90,5 \\
\hline Anfotericina B & 4 & 23 & 13 & 17 & 57 & 7,4 \\
\hline $\begin{array}{l}\text { Anfotericina } \\
\text { lipossomal }\end{array}$ & B & 2 & 4 & 4 & 11 & 1,5 \\
\hline Total & 255 & 283 & 163 & 68 & 769 & $100 \%$ \\
\hline
\end{tabular}

Legenda: LV: Leishmaniose visceral; FA: Frequência absoluta; FR (\%): Frequência relativa Ign: ignorado 
De acordo com a evolução, 94,4\% dos pacientes obtiveram cura e $3.3 \%$ foram a óbito. Em 2008 e 2010, a letalidade foi de 5\% e 5,9\%, respectivamente (TABELA 13).

TABELA 13 - Evolução dos casos de LV confirmados segundo o ano de notificação

\begin{tabular}{|c|c|c|c|c|c|c|c|c|c|c|}
\hline \multirow[t]{2}{*}{ Evolução } & \multicolumn{2}{|c|}{2007} & \multicolumn{2}{|c|}{2008} & \multicolumn{2}{|c|}{2009} & \multicolumn{2}{|c|}{2010} & \multicolumn{2}{|c|}{ Total } \\
\hline & FA & FR(\%) & FA & FR(\%) & FA I & FR(\%) & FA & FR(\%) & FA 1 & FR(\%) \\
\hline Cura & 244 & 95,6 & 264 & 93,3 & 159 & 97,6 & 62 & 91,2 & 729 & 94,9 \\
\hline Abandono & 2 & 0,8 & 0 & 0 & 0 & 0 & 0 & 0 & 2 & 0,2 \\
\hline Óbito por LV & 4 & 1,6 & 14 & 5 & 3 & 1,8 & 4 & 5,9 & 25 & 3,3 \\
\hline $\begin{array}{l}\text { Óbito por } \\
\text { outra causa }\end{array}$ & 2 & 0,8 & 3 & 1 & 1 & 0,6 & 2 & 2,9 & 8 & 1 \\
\hline Transferência & 3 & 1,2 & 2 & 0,7 & 0 & 0 & 0 & 0 & 5 & 0,6 \\
\hline Total & 255 & $100 \%$ & 283 & $100 \%$ & 163 & $100 \%$ & 68 & $100 \%$ & 769 & $100 \%$ \\
\hline
\end{tabular}

\subsection{Avaliação Demográfica da Amostra Estudada por Sorologia para LV}

A amostra estudada foi constituída por 391 soros. Destes, 191 foram de pacientes que não apresentavam clínica de LV e de nenhuma outra protozoonose; 100 foram considerados suspeitos, pois apresentavam clínica de LV, porém o resultado da RIFI foi negativo; e 100 foram considerados positivos, pois os resultados da RIFI foram positivos. Houve um predomínio de soros de pacientes na faixa etária de 20 a 34 anos (93 soros), 1 a 4 anos (79 soros) e 5 a 9 anos (54 soros) (TAB. 14). 
TABELA 14 - Distribuição da amostra estudada por faixa etária e sexo

\begin{tabular}{|c|c|c|c|c|c|c|c|}
\hline \multirow[t]{2}{*}{ Faixa Etária } & \multicolumn{2}{|c|}{$\begin{array}{l}\text { Soros } \\
\text { não-suspeitos }\end{array}$} & \multicolumn{2}{|c|}{\begin{tabular}{|l} 
Soros \\
suspeitos \\
\end{tabular}} & \multicolumn{2}{|c|}{$\begin{array}{l}\text { Soros } \\
\text { positivos }\end{array}$} & \multirow[t]{2}{*}{ Total } \\
\hline & Masc. & Fem. & Masc. & Fem. & Masc. & Fem. & \\
\hline$<1$ ano & 4 & 0 & 0 & 1 & 1 & 0 & 6 \\
\hline 1 a 4 & 17 & 14 & 14 & 13 & 6 & 15 & 79 \\
\hline 5 a 9 & 10 & 17 & 10 & 3 & 10 & 4 & 54 \\
\hline 10 a 14 & 6 & 8 & 8 & 1 & 5 & 3 & 31 \\
\hline 15 a 19 & 5 & 21 & 1 & 3 & 6 & 6 & 42 \\
\hline 20 a 34 & 19 & 31 & 13 & 5 & 15 & 10 & 93 \\
\hline 35 a 49 & 11 & 8 & 7 & 6 & 3 & 6 & 41 \\
\hline 50 a 64 & 7 & 5 & 4 & 4 & 4 & 2 & 26 \\
\hline 65 a 79 & 5 & 2 & 3 & 3 & 4 & 0 & 17 \\
\hline $80 \mathrm{e}+$ & 0 & 0 & 0 & 1 & 0 & 0 & 1 \\
\hline Subtotal & 84 & 107 & 60 & 40 & 54 & 46 & 391 \\
\hline Total & 19 & & 100 & & 10 & & 391 \\
\hline
\end{tabular}

Legenda: Masc.: masculino; Fem.: feminino

\subsection{Reprodutibilidade dos Ensaios Imunoenzimáticos Utilizando Antígeno de}

\section{Leishmania chagasi para Diagnóstico de LV}

Para o ELISAH, a reprodutibilidade da reação é alta, com $\mathrm{r}^{2}$ maior que 0.99 e pouca dispersão dos resultados em relação à reta de regressão linear (FIG5.).

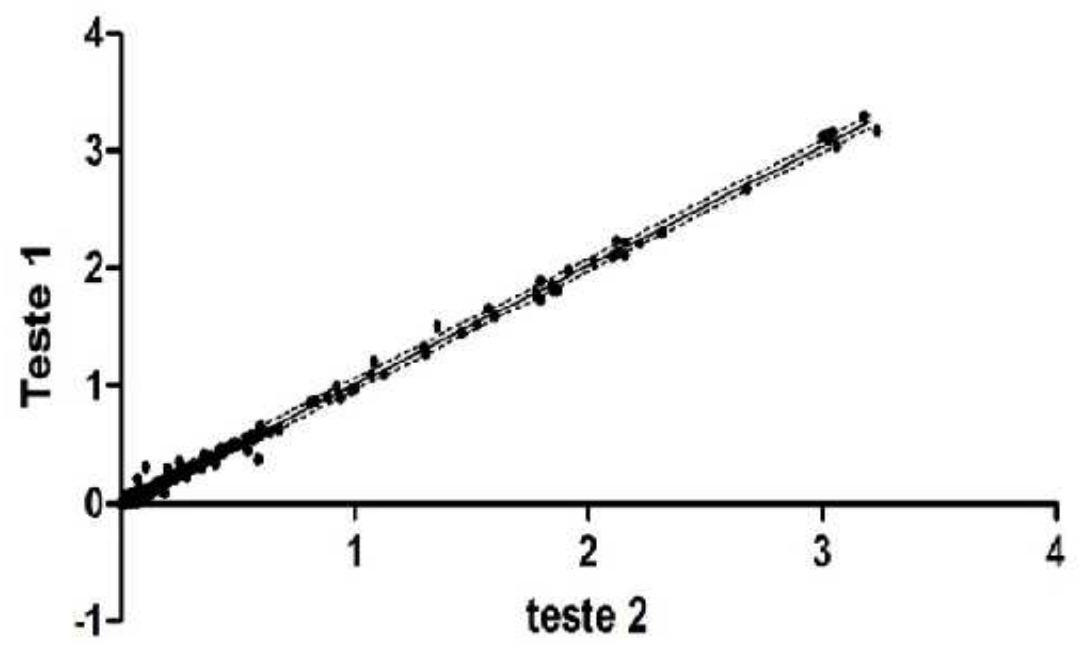

FIGURA 5 - Reprodutibilidade da reação de ELISAH in house (convencional) realizada em duplicata em soros humanos positivos e negativos para a RIFI e não-suspeitos para LVH 
O ensaio de ELISA dissociativo foi realizado nas mesmas condições e mostrou uma maior dispersão dos resultados de duplicatas, como pode ser visto na Figura 6. A correlação de valores era bastante elevada e atingiu um $r^{2}$ de 0,9689 , menor que o encontrado na ELISAH, com maior dispersão dos valores de duplicatas.

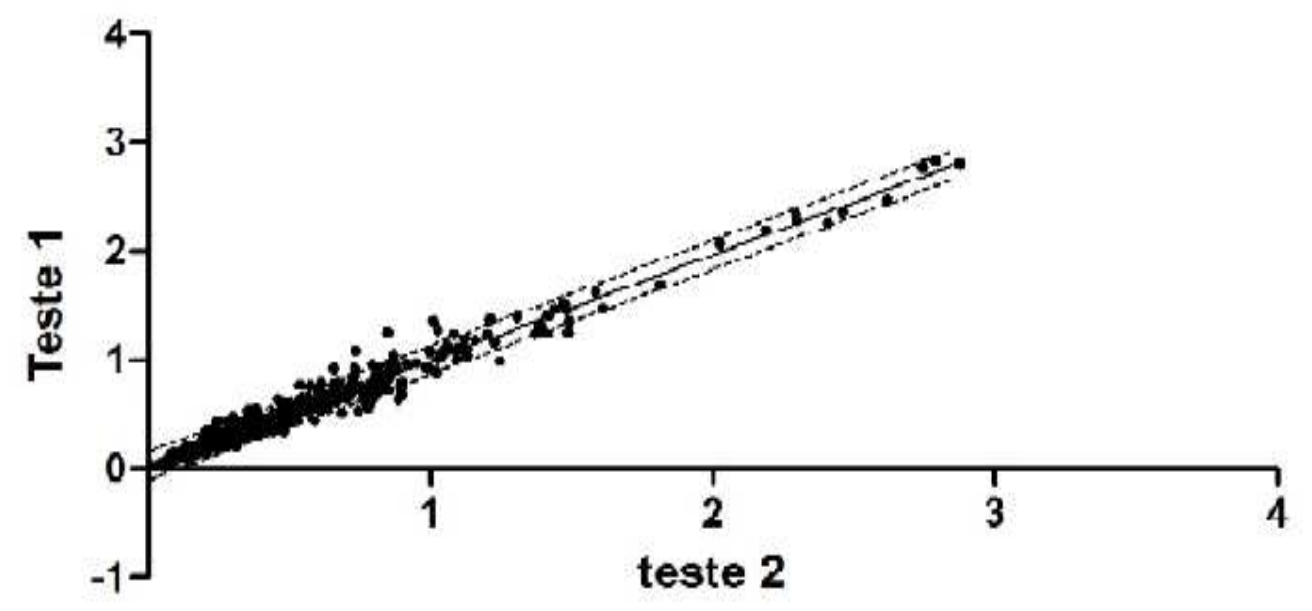

FIGURA 6 - Reprodutibilidade da reação de ELISAD (dissociativo) realizada em duplicata em soros humanos positivos e negativos para a RIFI e não-suspeitos para LVH

\subsection{Resultados Sorológicos}

No estudo, foi analisado, inicialmente, a amostra em relação aos resultados obtidos pela reação de rotina (RIFI) e pela reação de ELISA para IgG anti-Leishmania chagasi (ELISAH - convencional) e o ELISA dissociativo, efetuados para confirmação.

Das 100 amostras positivas para a RIFI, 59 foram positivas para os testes de ELISA convencional e dissociativo; 37 foram positivas apenas para o ELISA dissociativo; e 4 foram negativas para os testes de ELISA convencional e dissociativo. Das 100 amostras negativas para a RIFI, 68 foram negativas para os testes de ELISA convencional e dissociativo; 16 foram positivas apenas para o ELISA dissociativo; e 16 foram positivas para os testes de ELISA convencional e dissociativo (TAB.15). 
TABELA 15 - Distribuição da frequência dos soros positivos e negativos para a RIFI para LV por tipo final de classificação após os ensaios ELISA convencional e o dissociativo

\begin{tabular}{llccc}
\hline $\begin{array}{l}\text { Resultado da } \\
\text { RIFI de rotina }\end{array}$ & Classificação final & $\begin{array}{c}\text { Class. inicial } \\
\text { Positivo }\end{array}$ & $\begin{array}{c}\text { Class. inicial } \\
\text { Suspeito }\end{array}$ & Total \\
\hline \multirow{3}{*}{ Positivo } & Negativo & 4 & 0 & 4 \\
& Positivo (ELISAD) & 37 & 0 & 37 \\
& Positivo (ELISAH e ELISAD) & 59 & 0 & 59 \\
\hline Total positivo & & 100 & & 100 \\
\hline \multirow{3}{*}{ Negativo } & Negativo & & 68 & 68 \\
& Positivo (ELISAD) & & 16 & 16 \\
& Positivo (ELISAH e ELISAD) & & 16 & 16 \\
\hline Total negativos & & & 100 & 100 \\
\hline Total da amostra & & & 100 & 200 \\
\hline
\end{tabular}

Legenda: LV: Leishmaniose visceral; ELISA: imunoensaioenzimático; RIFI: Reação de imunofluorescência Indireta; ELISAD: ELISA dissociativo; ELISAH: ELISA convencional; Class: classificação

Das 75 amostras positivas para a RIFI 1:80, 40 foram positivas para os testes de ELISA convencional e dissociativo; 32 foram positivas apenas para o ELISA dissociativo; e 4 foram negativas para os testes de ELISA convencional e dissociativo. Das 25 amostras positivas para a RIFI 1:160, 19 foram positivas para os testes de ELISA convencional e dissociativo; 5 foram positivas apenas para o ELISA dissociativo; e 1 foi negativa para os testes de ELISA convencional e dissociativo (TAB.16).

TABELA 16 - Distribuição da frequência dos soros negativos e positivos nas diluições 1:80 e 1:160 para a RIFI para LV por tipo final de classificação após os ensaios ELISA convencional e o dissociativo

\begin{tabular}{|c|c|c|c|c|}
\hline $\begin{array}{l}\text { Resultado da } \\
\text { RIFI de } \\
\text { rotina }\end{array}$ & Classificação final & $\begin{array}{c}\text { Classificação } \\
\text { inicial } \\
\text { Positivo }\end{array}$ & $\begin{array}{c}\text { Classificação } \\
\text { inicial } \\
\text { Suspeito }\end{array}$ & Total \\
\hline \multirow{3}{*}{ Negativo } & Negativo & 0 & 68 & 68 \\
\hline & Positivo (ELISAD) & 0 & 16 & 16 \\
\hline & Positivo (ELISAH e ELISAD) & 0 & 16 & 16 \\
\hline Total negativo & & & 100 & 100 \\
\hline \multirow{3}{*}{ Positivo: 1:80 } & Negativo & 4 & 0 & 4 \\
\hline & Positivo (ELISAD) & 32 & 0 & 32 \\
\hline & Positivo (ELISAH e ELISAD) & 40 & 0 & 40 \\
\hline \multirow{3}{*}{ Positivo: 1:160 } & Negativo & 1 & 0 & 1 \\
\hline & Positivo (ELISAD) & 5 & 0 & 5 \\
\hline & Positivo (ELISAH e ELISAD) & 19 & 0 & 19 \\
\hline Total positivo & & 100 & & 100 \\
\hline
\end{tabular}


A classificação tipo final mostrou que dos 178 soros negativos, anteriormente, 106 eram classificados como não-suspeitos (RIFI não realizada); 4, como positivos (RIFI positiva); e 68, como suspeito (RIFI negativa). A presença de imunocomplexos foi evidenciada em 127 soros, que, antes eram classificados como nãosuspeitos, 74; positivos, 37; e suspeitos, 16. A classificação final como positiva foi verificada em 86 soros, sendo que, primeiramente, foram considerados 10 não-suspeitos, 59 positivos e 16 suspeitos (TAB.17).

TABELA 17 - Distribuição da frequência dos soros não-suspeitos, positivos e negativos para a RIFI para LV por tipo final de classificação após os ensaios ELISA convencional e o dissociativo

\begin{tabular}{lcccc}
\hline Classificação final & $\begin{array}{c}\text { Classificação } \\
\text { inicial } \\
\text { Não-suspeito }\end{array}$ & $\begin{array}{c}\text { Classificação } \\
\text { inicial } \\
\text { Positivo }\end{array}$ & $\begin{array}{c}\text { Classificação } \\
\text { inicial } \\
\text { Suspeito }\end{array}$ & Total \\
\hline Negativo & 107 & 4 & 68 & 178 \\
Positivo (ELISAD) & 74 & 37 & 16 & 127 \\
Positivo (ELISAH e ELISAD) & 10 & 59 & 16 & 86 \\
\hline & 191 & 100 & 100 & 391 \\
\hline
\end{tabular}

Legenda: LV: Leishmaniose visceral; ELISA: imunoensaioenzimático; RIFI: Reação de imunofluorescência Indireta; ELISAD: ELISA dissociativo; ELISAH: ELISA convencional.

\subsection{Comparação Quantitativa dos Testes Sorológicos}

Para comparação de reatividade relativa entre os dois ELISA utilizados nas amostras, mostramos sua distribuição na figura 7. Como pode ser observado, existe um grupo de amostras que é reagente ao ELISA dissociativo e não-reagente no ELISA clássico, que podem representar amostras de pacientes com imunocomplexos e com doença ativa. 


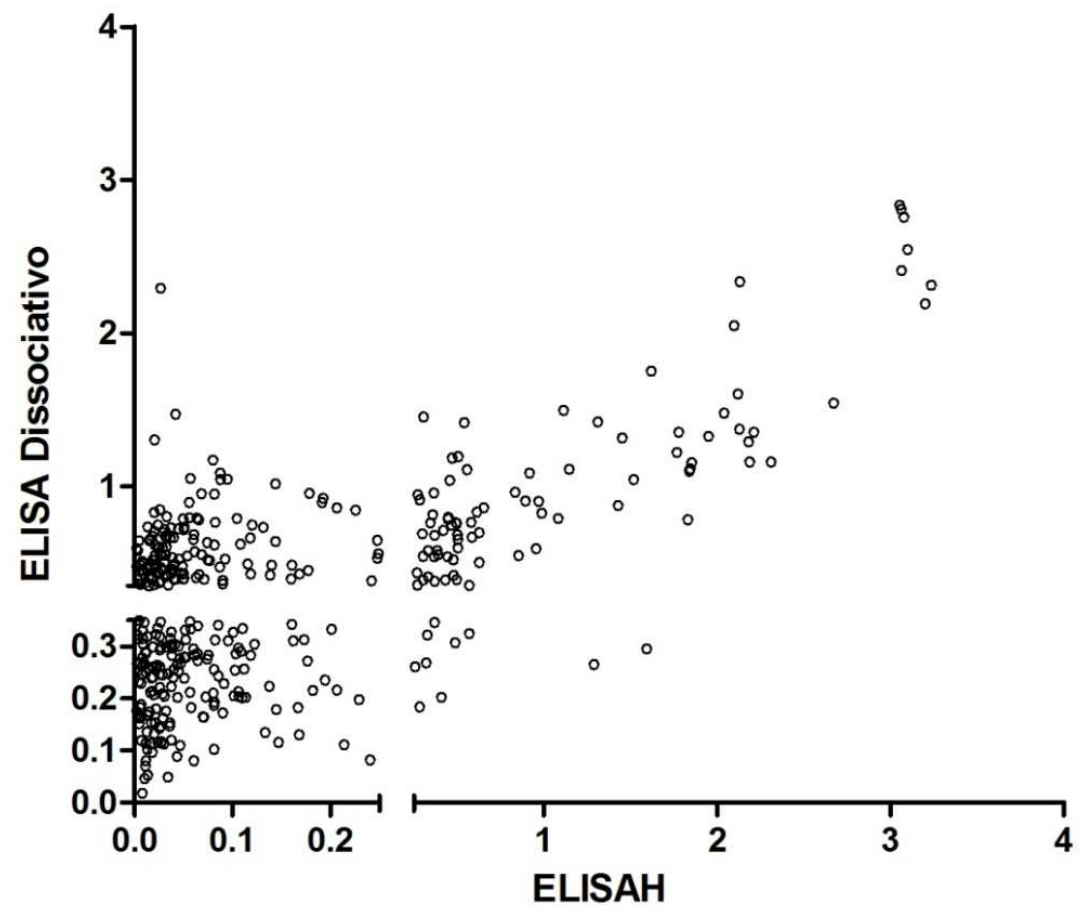

FIGURA 7 - Distribuição da reatividade dos ensaios de ELISAH(convencional)

e ELISA dissociativo dos soros positivos e negativos para RIFI para LVH.

A distribuição quantitativa do ELISAH em relação ao resultado qualitativo da RIFI pode ser visto na figura 8. Como pode ser observado, a positividade na RIFI foi frequentemente não encontrada no ELISA e, também, ocorrem falsos-negativos da RIFI neste ensaio, inclusive com altas densidade ópticas. Interessante o achado de amostras positivas em paciente assintomáticos. 


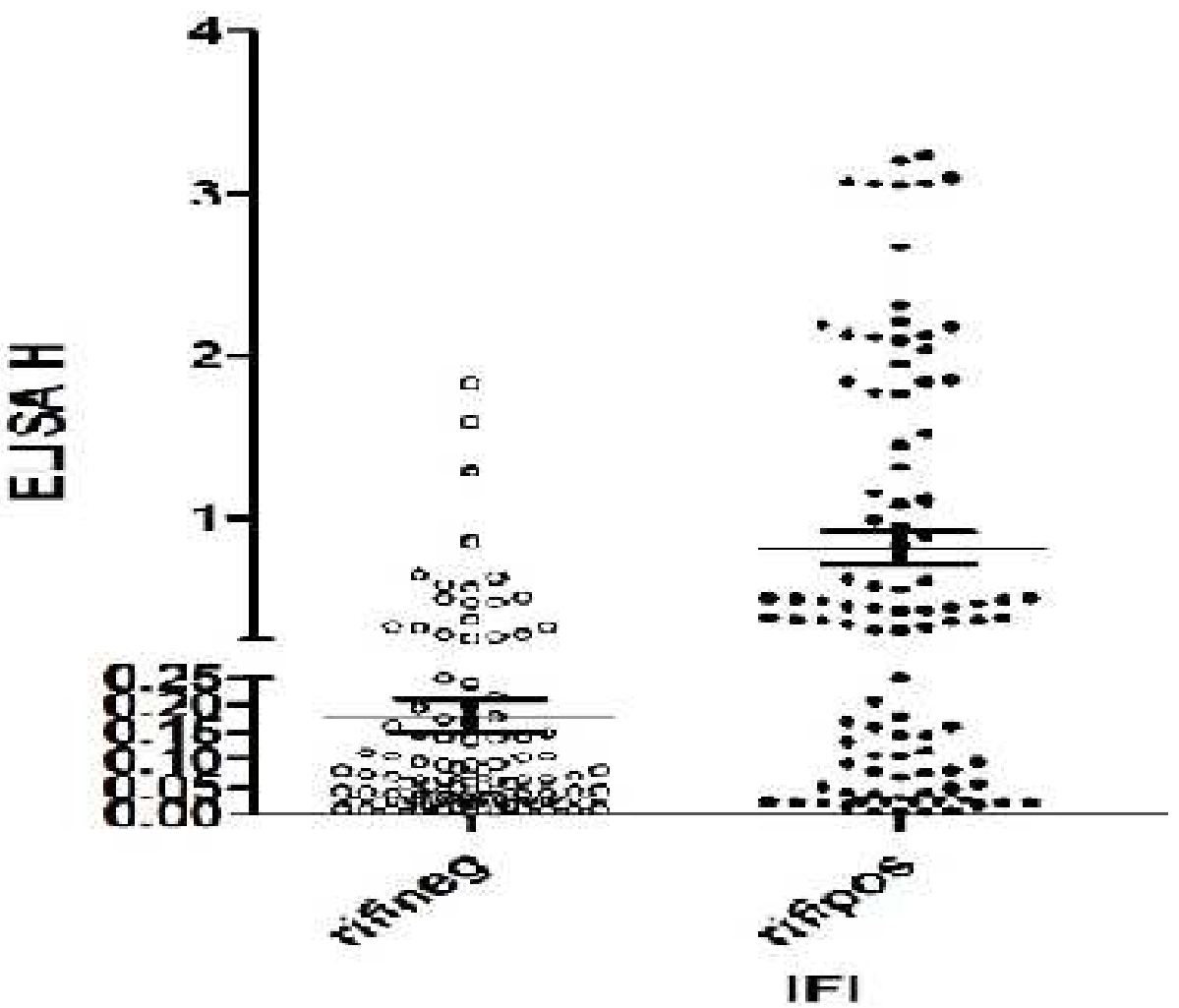

FIGURA 8 - Distribuição quantitativa do ELISAH em relação ao resultado qualitativo da IFI

Legenda: ELISAH: imunoensaioenzimático convencional; IFI: imunofluorescência indireta; rifineg: reação de imunofluorescência indireta negativa; rifipos: reação de imunofluorescência indireta positiva.

O mesmo tipo de seleção tambem foi aplicado aos resultados do ELISA dissociativo, como pode ser visto na figura 9. Como pode ser observado, a concordância deste ensaio com a RIFI é muito maior nos positivos. 


\section{einsadissoc}
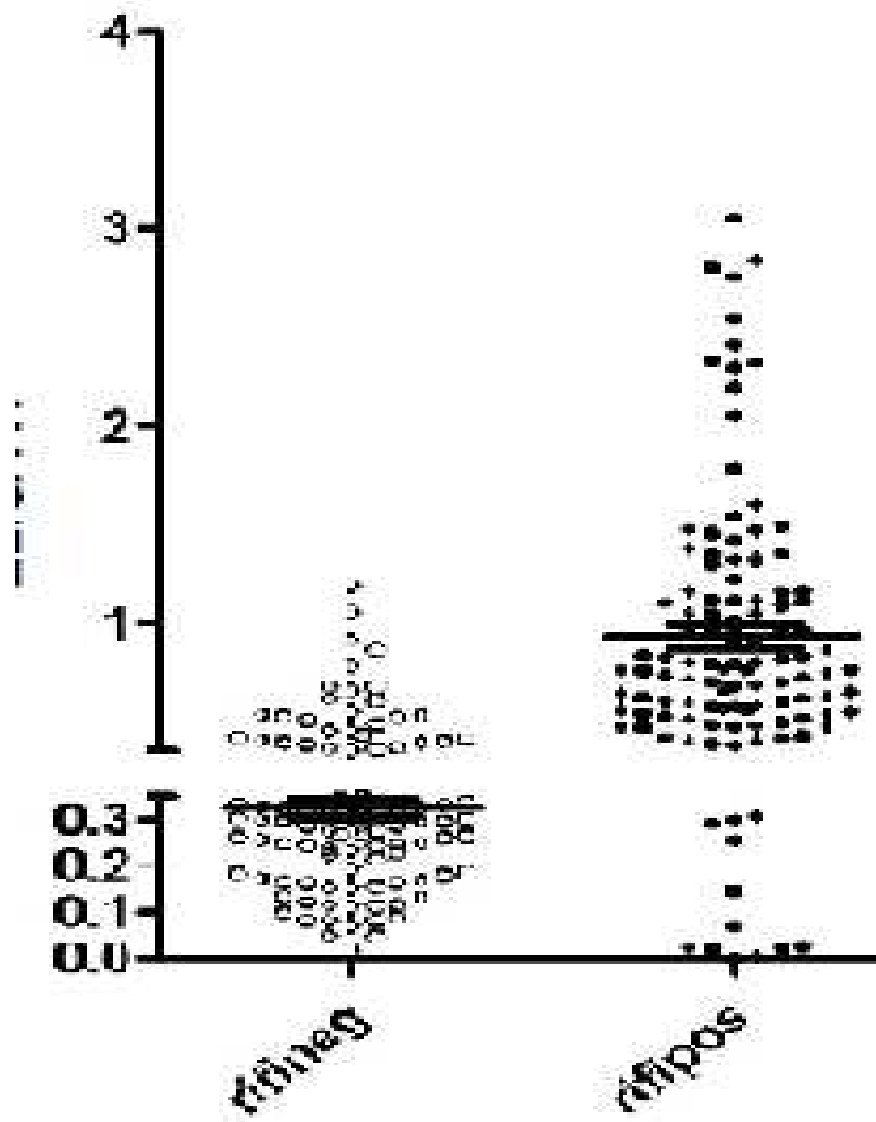

\section{달}
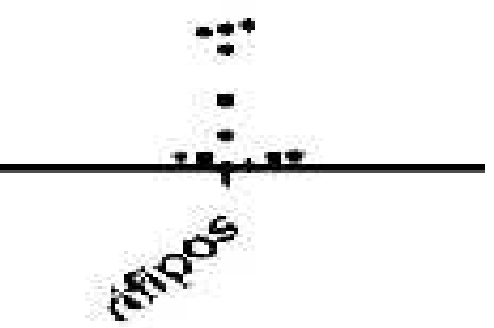

IFI

FIGURA 9 - Distribuição quantitativa do ELISA dissociativo em relação ao resultado qualitativo da IFI

Legenda: ELISAH: imunoensaioenzimático convencional; elisadissoc.: imunoenzimático dissociativo; IFI: imunofluorescência indireta; rifineg: reação de imunofluorescência indireta negativa; rifipos: reação de imunofluorescência indireta positiva. 


\section{DISCUSSÃO}

Cerca de três mil pessoas morrem no mundo por dia vítimas de doenças negligenciadas como leishmaniose visceral, doença de Chagas, malária e doença do sono. São mais de 1 milhão de mortes por ano. Um dos motivos para esse número elevado de óbitos é a falta de ferramentas adequadas para o diagnóstico e tratamento destas doenças. Elas afetam as populações mais empobrecidas nos países menos desenvolvidos do mundo, e, portanto, não constituem um mercado lucrativo para as indústrias farmacêuticas. Apenas 1,3\% dos medicamentos disponibilizados entre 1975 e 2004 foram para as doenças negligenciadas, apesar de representarem $12 \%$ da carga global de doenças. A LVH é uma protozoonose sistêmica grave, que pode acarretar morte nos pacientes não-tratados. No passado, era uma doença praticamente silvestre com características ambientais rurais, que tem apresentado mudança no comportamento epidemiológico, com uma tendência crescente no Brasil (Ministério da Saúde, 2008).

$\mathrm{Na}$ distribuição dos casos de LVH nos municípios do norte do estado do Tocantins, Araguaína representa 79,8\% no total dos casos no período de 2.007 a agosto de 2.010 (TAB. 2). Os resultados deste estudo revelaram que, nesse período, dos 882 casos confirmados de leishmanioses no município de Araguaína (TO), 769 (87,2\%) foram de LVH (TAB. 3 e 4). De acordo com o CCZ, em 2007, foram coletadas 6.525 amostras de sangue canino, sendo que 2.290 foram positivas para leishmaniose, evidenciando uma franca expansão da doença. Segundo o Ministério da Saúde, estima-se que para cada caso humano há em média 200 cães infectados. Dos casos confirmados, 98,7\% são de casos novos (TAB. 5) o que mostra a alta magnitude da doença, classificando o município como área de transmissão intensa de LV no Brasil (Ministério da Saúde, 2006). Houve um aumento significativo em 2.008, o que sinaliza a ineficiência das medidas preventivas, medidas de controle e tratamento tardio; e que pode ser atribuído, também, à falta de integração nas medidas de controle.

Com relação à distribuição por sexo, o estudo mostrou um predomínio do sexo masculino de 57,8\% em todos os anos analisados (TAB.6). A literatura aponta o sexo masculino como mais susceptível ao adoecimento. Essa também é uma característica comum encontrada em diversos estudos já publicados, que pode ser atribuída a fatores 
genéticos e de uma maior exposição do homem pela sua ocupação (Alvarenga, 2008). A faixa etária mais acometida foi a de 0 a 14 anos, com 71,3\% dos casos notificados, sendo mais freqüente em crianças menores de 4 anos, com 51,8\% (TAB.7). A razão de maior susceptibilidade das crianças pode ser explicada pelo estado de relativa imaturidade celular agravado pela desnutrição, tão comum nas áreas endêmicas, além de maior exposição ao vetor no peridomicílio (Queiroz et al, 2004). Estes resultados coincidem com os dados do Ministério da Saúde (2008) e com estudos realizados em outros municípios, como Cuiabá (Mestre, 2007) e Campo Grande (Alvarenga, 2008; Furlan, 2010).

A mudança no padrão de transmissão da doença deve-se principalmente à urbanização do vetor, à participação do cão como reservatório doméstico da $L$. (L.) chagasi e à degradação ambiental, juntamente com o processo migratório da população para os grandes centros urbanos.

$\mathrm{Na}$ distribuição por zona de residência, foram notificados $98,5 \%$ dos casos na zona urbana (TAB.8), mostrando a urbanização da LV, que pode ser atribuída às transformações no ambiente, provocadas pelo intenso processo migratório, por pressões econômicas ou sociais, a pauperização conseqüente de distorções na distribuição de renda, o processo de urbanização crescente, o esvaziamento rural e as secas periódicas que acarretam a expansão das áreas endêmicas e o aparecimento de novos focos. Este fenômeno leva a uma redução do espaço ecológico da doença, facilitando a ocorrência de epidemias (Ministério da Saúde, 2008) Resultados semelhantes foram encontrados em Feira de Santana (BA) (Carneiro et al, 2004), Belo Horizonte (MG) (Bevilacqua et al, 2001), São Luís (MA) (Caldas et al, 2001)

Com características de doença re-emergente em franca expansão, a LV vem se constituindo um grave problema de saúde pública no Brasil em conseqüência das ações antrópicas no meio ambiente, onde o flebotomíneo vetor encontra condições propícias para a manutenção do seu ciclo de vida somadas ao seu raio de ação, numa média de 250 a 500m (Carneiro et al, 2004).

Nos últimos vinte anos, em Araguaína, tem havido uma maior migração de pessoas da zona rural para a urbana. Novos migrantes se fixam em aglomerações superlotadas e inadequadas, construídas na periferia da cidade, geralmente em áreas recentemente habitadas à custa de queimadas e desmatamentos. Estas condições traduzem em excelente habitat para o flebotomíneo vetor (Nascimento et al, 2005). 
Com relação à distribuição dos casos confirmados de LV por bairros de residência, os que apresentaram maior número de casos foram Nova Araguaína, 12\%; Araguaína Sul, 10,9\%; São João, 6,6\%; e Maracanã, com 6,4\% dos casos confirmados (TAB. 8). Esses bairros são habitados por moradores de baixa renda e desprovidos de rede de esgoto. As condições de moradia e higiênico-sanitárias são precárias nessas localidades, sugerindo a presença de outras infecções parasitárias. Devido ao desmatamento desses locais, observa-se a presença de animais silvestres, o que pode ser um fator de disseminação e maior circulação do parasita.

De acordo com um estudo realizado por Gomes, 2008, em Araguaína, 68\% dos bairros deste município apresentaram a presença do Lutzomya longipalpis. As localidades que apresentaram maiores índices do vetor foram os setores Araguaína Sul, Maracanã, Nova Araguaína e Centro, considerados como área de transmissão intensa. A área central da cidade apresenta uma realidade fisico-socio-ambiental muito diferente das anteriores, por se tratar de um local onde há coleta de lixo regularmente, rede de água e de energia elétrica, condições socioeconômicas e higienico-sanitárias satisfatórias, demonstrando, assim, um acentuado grau de adaptação dessa espécie nas áreas sob influência antrópica (Gomes, 2008).

O diagnóstico clínico-epidemiológico é insuficiente para justificar o tratamento, já que a apresentação clínica da LV é comum a diversas outras patologias. As manifestações clínicas mais frequentes foram febre, fraqueza, palidez, emagrecimento, aumento de baço e fígado (TAB. 9). Estes resultados corroboram os de Três Lagoas (MS) (Oliveira et al, 2006), Campo Grande (MS) (Alvarenga, 2008; Furlan, 2010; Mestre, 2007).

Os casos de LV, 99,5\% tiveram como confirmação o diagnóstico laboratorial (TAB. 10). Dos métodos de diagnóstico laboratorial, o mais utilizado foi a Reação de Imunofluorescência Indireta (RIFI) para Leishmaniose Humana, em 97,8\% dos casos (TAB. 11).

A RIFI é favorecida pela expressiva resposta imune humoral que caracteriza a doença, porém a pesquisa de anticorpos deixa a desejar no que se concerne à especificidade (78 a 92\%) e sensibilidade (82 a 95\%) (Assis et al, 2007), o que leva a resultados falso-positivos, por reações cruzadas com outras doenças causadas por protozoários, como a Doença de Chagas e toxoplasmose. Este fato chama atenção, pois de 
acordo com uma pesquisa realizada em Araguaína por Corrêa, em 2010, onde vários casos de Doenças de Chagas foram notificados, o que pode levar a reação cruzada, e que consequentemente, resultados falso-positivos para LV irão aparecer.

Pacientes parasitados com alta carga antigênica, porém imunocomplexada, ou com anticorpos de baixa afinidade podem apresentar resultados falso-negativos para RIFI, retardando o tratamento farmacológico e agravando o quadro clínico do paciente.

Com relação ao tratamento, $90,5 \%$ dos pacientes receberam como droga inicial o antimônio pentavalente (TAB. 12). Mesmo com a instituição do tratamento, 1 a 5\% dos afetados morrem como resultado da resistência à quimioterapia, pela toxicidade dos quimioterápicos; ou como conseqüência de complicações da doença, principalmente quando o diagnóstico é tardio, sendo uma das preocupações atuais com LV a sua elevada letalidade: próxima a $100 \%$ em pacientes não-tratados. Neste estudo, de acordo com a evolução, 94,4\% dos pacientes obtiveram cura e 3.3\% foram a óbito (TAB. 13).

Nos ensaios foram utilizadas uma abordagem usual da rede do Sistema Único de Saúde (SUS), o ensaio de imunofluorescência indireta utilizando promastigotas de L.major; um ELISA convencional, utilizando antígeno de L.chagasi na fase sólida; e um ELISA dissociativo, utilizando o último antígeno e a dissociação ácida, o que indica indiretamente a presença de imunocomplexos. Ressalta-se que o ensaio ELISAD foi testado pela primeira vez em humanos neste estudo. Os ensaios de ELISA apresentaram alta reprodutibilidade. Não houve diferenças demográficas como sexo e idade nas populações estudadas e em sua positividade por qualquer dos três testes utilizados.

Os pacientes positivos apresentam uma frequência de 4\% (4/100) de falsopositivos quando testados em ambos os ELISA, com uma maior taxa de positivos no ELISA convencional e dissociativo juntos (59/100), enquanto que o ELISA dissociativo apresentou 37/100 positivos.

Entre os pacientes suspeitos, houve uma alta freqüência de positivos ao ELISA, maior no ELISA dissociativo (32/100) do que no ELISA convencional (16/100). Na população assintomática, houve um achado de 74/191 amostras positivas ao ELISA dissociativo e 10/191 positivas ao ELISA convencional. A associação de RIFI com ELISA convencional e dissociativo permitiu a confirmação diagnóstica em $96 \%$ dos pacientes positivos. Estas diferenças de reatividade se deve a vários fatores, a saber, a maior exposição de antígenos internos no ELISA quando comparado à RIFI, restrita a antígenos 
de superfície, uma diferença na espécie de leishmania utilizada para produzir o antígeno ou ainda a fatores da própria doença, como demonstrado pela maior positividade do ELISA dissociativo que pode estar associada a presença de imunocomplexo circulantes e que foi mais concordante com a IFI 1:160.

A presença de imunocomplexos em pacientes assintomáticos no início da doença ou sua presença em pacientes com resposta humoral menos intensa, como crianças, pode explicar estes achados de maior positividade no ELISA dissociativo. A confirmação destes efeitos depende da pesquisa parasitológica em pacientes positivos ao ELISA dissociativo. Em um estudo realizado por Carvalho, em 2010, foram testadas amostras de cães com infecção natural parasitológica por L.(L) chagasi, provenientes de áreas endêmicas do estado de São Paulo. O teste imunoenzimático com a dissociação de imunocomplexos apresentou alta positividade nas amostras negativas ao teste de ELISA convencional, mostrando que a presença de imunocomplexos interfere no diagnóstico sorológico. Estes resultados mostram a importância de novas abordagens sorológicas no diagnóstico da leishmaniose visceral humana, de baixo custo operacional e de fácil execução, que viabilizariam uma triagem de paciente para diagnóstico parasitológico invasivo, que é arriscado por hemorragia em decorrência à trombocitopenia, freqüente nestes pacientes (Carvalho, 2010). 


\section{CONCLUSÃO}

Em 2009, a LVH ocupou o $2^{\circ}$ lugar nas doenças infecto-parasitárias de notificação compulsória no município de Araguaína, perdendo apenas para a dengue, representando 79,8\% dos casos confirmados na região norte do Tocantins no período de 2007 a agosto de 2010 . Houve um predomínio de casos do sexo masculino $(57,8 \%)$ e na faixa etária de 0 a 14 anos (71,3\%) e constatou-se a urbanização da doença, com 98,5\% dos casos com zona de residência urbana.

O processo de expansão geográfica e urbanização da LVH no município de Araguaína levam à necessidade de estabelecimento de medidas eficientes e rápidas contra a doença. Nesse contexto, a valorização e incentivo de novas pesquisas sobre o tema têm papel relevante na erradicação da doença.

Em razão das dificuldades encontradas no diagnóstico da LV em áreas endêmicas, é urgente o emprego de técnicas simples, de baixo custo e fácil execução e que apresentem elevada sensibilidade e especificidade, com o intuito de diminuir falsos resultados, tanto os falsos-negativos, que inviabilizam o tratamento precoce, quanto os falsos-positivos, que levam ao tratamento desnecessário, gerando custos para o SUS e reações adversas severas aos pacientes.

As dificuldades em se estabelecer o diagnóstico foram evidenciadas pelas reações falso-positivas e falso-negativas da RIFI, que é o principal método de diagnóstico utilizado pelo LSP, que é o laboratório de referência na região para doenças infectocontagiosas. Outros métodos foram testados e se mostraram de maior eficiência como o ELISA dissociativo. O ensaio de ELISAD mostrou-se uma ferramenta promissora no sentido de diminuir falsos resultados. 


\section{ANEXO}

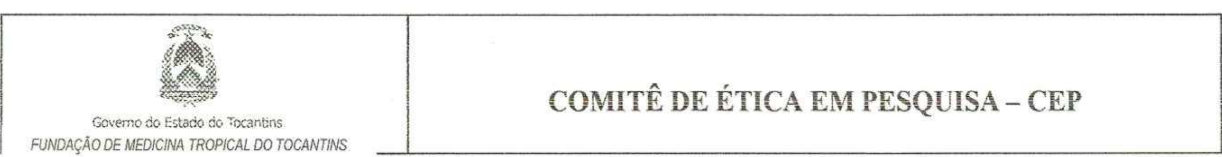

\begin{tabular}{|l|c|c|}
\hline \multicolumn{2}{|c|}{ PARECER CONSUBSTANCIADO } & \multirow{2}{*}{ PROCESSO No } \\
\hline PROJETO DE PESQUISA & $\mathbf{x}$ & $\underline{079 / 2010}$ \\
\hline TRABALHO DE CONCLUSÃO DE CURSO & & \\
\hline
\end{tabular}

O parecer consubstanciado do relator será utilizado como subsídio para o Comitê de Ética em Pesquisa da Fundação de Medicina Tropical do Tocantins elaborar seu parecer final.

1-Identificação da Proposta de Projeto de Pesquisa/Trabalho de Conclusão de Curso
\begin{tabular}{|l|} 
Título: \\
EPIDEMIOLOGIA DA LEISHMANIOSE VISCERAL HUMANA EM ARAGUAINA (TO) E O \\
DIAGNÓSTICO SOROLÓGICO DA DOENÇA EM ATIVIDADE \\
\hline Coordenador do Projeto ou Professor Orientador do TCC: \\
Anette Kelsei Partata \\
\hline $\begin{array}{l}\text { Pesquisadores Participantes: } \\
\text { Anette Kelsei Partata } \\
\text { Nanci do Nascimento }\end{array}$ \\
\hline Curso/ Faculdade: \\
Instituto de Pesquisas Energéticas e Nucleares - IPEN/Universidade de São Paulo-USP \\
\hline
\end{tabular}

\section{2- Análise do Projeto de Pesquisa/Trabalho de Conciusão de Curso}

0 projeto busca contribuir com as ações propostas pelo Programa de Controle da Leishmaniose Visceral (LV), através da realização de um levantamento epidemiológico dos casos diagnosticados da doença no município de Araguaína-TO e, propõe ainda colaborar no diagnóstico da patologia por meio da comparação de abordagens sorológicas em amostras de pacientes com diferentes condições clínicas.

2.1 - Objetivos e Adequaç̃o metodológica (Verificar a exeqüibilidade da proposta, isto é, se existe clareza do objeto, compatibilidade entre os objetivos, a fundamentação teórica e a metodologia ou plano de ação, evidenciando consistência entre objetivos, procedimentos, açōes de execução da pesquisa e capacidade do proponente, demonstrada por outros trabalhos similares.)

- A pesquisa é exequível.

- 0 projeto apresenta fundamentação teórica adequada e seus objetivos são alcançáveis através da metodologia descrita.

2.2 - Avaliação do Questionário a ser aplicado e do Termo de Consentimento Livre e Esclarecido:

- TCLE: não se aplica.

2.3 - Revisão Bibliográfica

- A revisão bibliográfica é satisfatória.

3 - Qualificação do Pesquisador/Orientador (Indicar os atributos do Pesquisador/Orientador, salientando a titulação e experiência compativel com a função de orientação; qualidade e regularidade da produção cientificatecnológica/artística, compativel com o projeto de pesquisa/Trabalho de Conclusão de Curso)

- As pesquisadoras estão aptas a executar a pesquisa proposta. 
4-Parecer conclusivo, recomendações e/ou sugestões:

- De acordo com os Itens VII.13.d e IX.2.c da Resolução CNS 196/96 é necessário que os pesquisadores enviem ao CEP relatórios parciais e final sobre a pesquisa realizada. Para atendimento à legislação vigente recomenda-se, para esta pesquisa, o envio de relatórios parciais anuais e final do projeto.

- O CEP FMTTO está disponível para sanar eventuais dúvidas das pesquisadoras.

5 - Pendências: (Enumerar sucintamente as pendências a serem sanadas pelo Coordenador do Projeto de Pesquisa Trabalho de Conclusão de Curso)

- Não se aplica.

6 - Parecer Consubstanciado

Aprovado $\bigotimes \quad$ Pendências $\square \quad$ Não aprovado $\square$

Assinatura do Coordenador do CEP: PV Verissa Martins Teixeira $\quad$ Data da reunião: 10/11/2010

Matricula: 860765.6

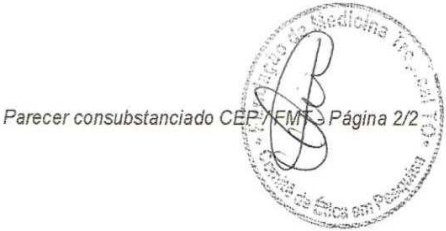




\section{REFERÊNCIAS}

ALVARENGA, DG. (2008) Estudo farmacoepidemiológico da leishmaniose visceral em adultos em Campo Grande (MS), 2002 - 2005. Governador Valadares.

ALVÁREZ-FORTES, E; RUIZ-PÉREZ, LM; BOUILLAUD, F; RIAL, E; RIVAS, L.(1998). Expression and regulation of mitochondrial uncoupling protein 1 from brown adipose tissue in Leishmania major promastigotes. Mol Bioc Parasitology 93 (2):191-202.

ALVES, CF. Determinação do perfil de citocinas e quantificação da carga parasitária em cães naturalmente infectados por leishmania (Leishmania) chagasi (Cunha e Chagas, 1937) com e sem expressão clínica da leishmaniose visceral. 2007. Tese de Doutorado - Universidade de Federal de Minas Gerais.

ALVES, JGB. CALAZAR. IN: FIGUEIRA, FFOS; ALVES; JGB. Pediatria-Instituto Materno Infantil de Pernambuco. 2 ed.Medsi,Rio de Janeiro, p.320-327,1996.

ANDRADE, TM; CARVALHO, EM; ROCHA, H. Bacterial infections in patients with visceral leishmaniasis. J Infect Dis 1990; 162: 1354-9.

ANTOINE JC, LANG T, PRINA E, COURRET N, HELLIO R (1999). H-2M molecules,like MHC class II molecules, are targeted to parasitophorous vacuoles of Leishmania infected macrophages and internalized by amastigotes of L. amazonensis and L. mexicana. J Cell Sci 112(15):2559-2570

ASSIS TSM, BRAGA ASC, PEDRAS MJ, BARRAL AMP, SIQUEIRA IC, COSTA CHN, COSTA DL, HOLANDA TA, SOARES VYR, BIÁ M, CALDAS AJM, ROMERO GAS, RABELLO A. Validação do teste imunocromatográfico rápido IT-LEISH ${ }^{\circledR}$ para o diagnóstico da leishmaniose visceral humana. Epidemiologia e Serviços de Saúde 2007; 17(2): 107-116.

BEVILACQUA PD, PAIXÃO HH, MODENA CM, CASTRO MCPS. Urbanização da leishmaniose visceral em Belo Horizonte. Arquivo Brasileiro de Medicina Veterinária e Zootecnia 53:1-8, 2001.

BORBOREMA SET. Desenvolvimento e farmacocinética de antimônio encapsulado em lipossomas de fosfatidilserina utilizando radioisótopos em leishmaniose experimental. Dissertação de Mestrado. 2009 - Instituto de pesquisas Energéticas e Nucleares, São Paulo.

BRASIL, 2004. Manual de Recomendação para Diagnóstico, Tratamento e Acompanhamento da Co-infecção Leishmania/HIV. Ministério da Saúde (MS)/ Secretaria de Vigilância em Saúde (SVS). Programa Nacional de DST e Aids. Brasília. DF. 2004. 
BRASIL. Ministério da Saúde. Leishmaniose visceral grave: normas e condutas. Ministérios da Saúde, Brasília, 2005.

CALDAS, A. J. M.; SILVA, D. R. C.; PEREIRA, C. C. R.; NUNES, P. M. S.; SILVA, B. P.; SILVA, A. A. M.; BARRAL, A. \& COSTA, J. M. L., 2001. Infecção por Leishmania (leishmania) chagasi em crianças de uma área endêmica de leishmaniose visceral americana na Ilha de São Luís - MA, Brasil. Revista da Sociedade Brasileira de Medicina Tropical, 34:15-21.

CAMARGO-NEVES, VERA LÚCIA FONSECA DE; SANTUCCI, SILVANA GAZOLA. Leishmaniose Visceral Americana. Superintendência de Controle de Endemias - SUCEN, Coordenadoria de Controle de Doenças, Secretaria de Estado de Saúde de São Paulo, 2000-2001. Disponível em: <http://www.sucen.sp.gov.br/doencas/leish_visc/texto_leish_visc_pro.htm> Acesso em 31 jan. 2006.

CARNEIRO, DMT; BAVIA, ME; ROCHA, W; LOBÃO, J; MADUREIRA, C; OLIVEIRA, JB; SILVA, CE; BARBOSA, MGR; RIOS, RB. Identificação de áreas de risco para a leishmaniose visceral americana, através de estudos epidemiológicos e sensoriamento remoto orbital em Feira de Santana, Bahia, Brasil (2000-2002). Revista Baiana de Saúde Pública, v. 28, p. 19-32, 2004.

CARVALHO, C A; BORBOREMA, S. E. T., HIRAMOTO, R. M.; MEIRELES, L. R.; ANDRADE JR, H. Influência da dissociação de imunocomplexos na sorologia da leishmaniose visceral em cães naturalmente infectados por Leishmania chagasi, provenientes de áreas endêmicas do estado de São Paulo. VIII Encontro do Instituto Adolfo Lutz. São Paulo, SP. 2010.

CIMERMAN, SERGIO; CIMERMAN, BENJAMIM. Medicina Tropical. São Paulo: Editora Atheneu, 2003.

CHAVES-BORGES, FA; SOUZA, MA; SILVA, DAO; MINEO, JR. Detection of Toxoplasma gondii soluble antigen, SAG-1(p30), antibody and immune complex in the cerebrospinal fluid of HIV positive or negative individuals. Rev. Int. Med. Trop. S. Paulo, 41(6): 329-338. November-december, 1999.

CORRÊA, VR. Avaliação e epidemiologia da cardiopatia chagásica em pacientes atendidos em Araguaína - Tocantins. 2010. Dissertação de Mestrado. 2010. - Instituto de pesquisas Energéticas e Nucleares, São Paulo.

COSTA, JML. Epidemiologia das leishmanioses no Brasil. Gazeta Médica da Bahia 75:3-17, 2005.

COSTA, TL; SILVA, MG; RODRIGUES, IMX; BARBARESCO, AA; AVELINO, MM.; CASTRO, AM. Diagnóstico clínico e laboratorial da toxoplasmose. NewsLab 85 ed. 2007:88-104. 
DUARTE, MARIA IRMÃ SEIXAS. Leishmaniose Visceral (Calazar). In: FILHO, Geraldo Brasileiro. Patologia. 6. ed. Rio de Janeiro: Guanabara Koogan, 2000. Cap. 10, p 1215-1227.

ELKHOURY, ANA NILCE SILVEIRA MAIA. Vigilância e controle da leishmaniose visceral no Brasil. Secretaria de Vigilância em Saúde. Ministério da Saúde.2009.

FREDERIC, F; SCHETTINI, AD. Lipossomas: propriedades físico-químicas e farmacológicas, aplicações na quimioterapia a base de antimônio. Química Nova, São Paulo, v.28, n.3, p.511-518, 2005.

FURLAN, MBG. Epidemia de leishmaniose visceral no Município de Campo Grande - MS, 2002 a 2006. Epidemiologia e Serviços de Saúde 2010; 19(1):15-24.

GENARO, ODAIR. Leishmaniose Visceral Americana. In: Humana. 10 ed. São Paulo: Atheneu, p 56-72, 2003. Parasitologia

GOMES, KC. Estudo da fauna dos flebotomíneos no município de Araguaína (TO), no período de janeiro de 2006 a dezembro de 2007. Monografia da Especialização em Vigilância em Saúde: Controle de Zoonoses. FMT /IMT. Araguaína (TO). 2008

GONTIJO, CÉLIA MARIA FERREIRA; MELO, MARIA NORMA. Leishmaniose Visceral no Brasil: Quadro Atual, Desafios e Perspectivas. Revista Brasileira de Epidemiologia, v7, n3, p338-349, set. de 2004.

GOTO, H; PRIANTI, MG, (2009). Review immunoactivation and immunopathogeny during active visceral leishmaniasis. Rev. Inst. Med. Trop. S. Paulo. São Paulo, SP. Brasil, 51(5):241-146, september-octuber,.

IBGE. Instituto Brasileiro de Geografia e Estatística. Acesso em: 08/11/2010: http://www.ibge.gov.br/home/

LACHAUD L, DEREURE J, CHABBERT E, REYNES J, MAUBOUSSIN JM, OZIOL E, et al.Optimized PCR using patient blood sample for diagnosis and follow-up of visceral Leishmaniasis, with special reference to AIDS patients. J Clin Microbiol 2000; 38:236-40.

LAINSON R, RYAN L, SHAW JJ (1987). Infective stages of Leishmania in the sandfly vector and some observations on the mechanism of transmition. Mem. Inst. Oswaldo Cruz, Sep; 82 (3): 421-4.

LIMA, A.J. et al. Métodos de laboratório aplicados a clinica. Rio de Janeiro: Guanabara Koogan, 2001. 23-11p.

MACHADO MRM. Leishmaniose visceral: uma endemia em expansão no Brasil e emergente no Estado do Tocantins. (Dissertação de Mestrado), Universidade Federal de Goiás, Goiânia, GO, 2004. 
MALAFAIA, GUILHERME. Leishmaniose visceral no estado de Minas Gerais: panorama, desafios e perspectivas.SaBios Ver. Saúde e Biol., v.4, n.1, p.1-11. jan-jun. 2009.

MARZOCHI, MCA; MARZOCHI, KBF; SCHUBACH, AO. LEISHMANIOSE VISCERAL AMERICANA. IN: CIMERMAN, BEJAMIM; CIMERMAN, SÉRGIO. Parasitologia Humana e Seus Fundamentos Gerais. 2. ed. São Paulo: Editora Atheneu, 2008. p.65-78.

MEDEIROS, Iara Marques; NASCIMENTO, Eliana Lúcia Tomaz do; HINRICHSEN, Sylvia Lemos. Leishmanioses (Visceral e Tegumentar). In __. DIP - Doenças Infecciosas e Parasitárias. Rio de Janeiro: Guanabara Koogan, p 398-409, 2005.

MELO, M. N. Leishmaniose Visceral no Brasil: desafio e perspectivas. In: XIII Congresso Brasileiro de Parasitologia \& I Simpósio Latino-Americano de Ricketisioses, Ouro Preto, 2004. p. 41-45.

MESTRE G L C, FONTES C J F. A expansão da epidemia da leishmaniose visceral no Estado de Mato Grosso, 1998-2005. Rev Soc Bras Med Trop. 2007. 40: 42-48.

MICHALICK, MARILENE SUZAN MARQUES; GENARO, ODAIR. Leishmaniose Visceral Americana. In: NEVES, DAVID PEREIRA. Parasitologia Humana. 11. ed. São Paulo: Atheneu, 2005. Cap.10, p.67-83.

MINISTÉRIO DA SAÚDE. Fundação Nacional de Saúde. Centro Nacional de Epidemiologia. Leishmaniose Visceral no Brasil: Situação atual, principais aspectos epidemiológicos, clínicos e medidas de controle. Boletim Epidemiológico 6 : I-II, 2001

MINISTÉRIO DA SAÚDE. Manual de vigilância e controle da leishmaniose visceral.1 ed. Brasília. 2006.

MINISTÉRIO DA SAÚDE. Leishmaniose Visceral - Recomendações clínicas para redução da letalidade. Brasília: 2008.

MISSAWA, NANCI AKEMI; BORBA, JOAO FRANCISCO. Leishmaniose visceral no município de Várzea Grande, estado de Mato Grosso, no período de 1998 a 2007. Rev. Soc. Bras. Med. Trop. Vol.42 no.5 Uberaba spt.-oct. 2009.

MORENO, E; MELO, MN; ANTUNES, CMF; LAMBERTUCCI, JR; SERUFO, JC; ANDRADE-RIBEIRO, AS. Epidemiologia da Leishmaniose Visceral Humana assintomática em área urbana, Sabará, Minas Gerais, 1998-1999. Informe Epidemiólogico do SUS 2002; 11: 37-9.

NASCIMENTO, MDSB; SOUZA, EC; DA SILVA, LM; DA CUNHA, LEAL P; DE LIMA; CANTANHEDE, K; DE BARROS; BEZERRA, GF. Prevalência de infecção por Leishmania chagasi utilizando os métodos de ELISA (rK39 e CRUDE) e intradermorreação de Montenegro em área endêmica do Maranhão, Brasil. Cad Saúde Pública 2005;21:1801-7. 
NASCIMENTO, MDS; BEZERRA, GFB; BANDEIRA NETO, AP; SILVA, LM; BEZERRA, JM; VIANA, GMC. Estudo comparativo de anticorpos IgG e IgE antileishmania como marcadores de infecção e doença em indivíduos de área endêmica de leishmaniose visceral, em São Luis, MA. Rev. Soc. Bras. Med. Tropical 39(1):38-42, jan-fev, 2006.

NEVES, DAVID; MELO, ALAN; LINARDI, PEDRO; VITOR, RICARDO. Parasitologia Humana. $11^{\mathrm{a} e d .}$ São Paulo. Atheneu, 2005.

OLIVEIRA, A. L. L.; A. M. M. PANIAGO; M. E. C. DORVAL; E. T. OSHIRO; C. R. LEAL; M. SANCHES; R. V. CUNHA \& M. N. BÓIA. (2006). Foco emergente de leishmaniose visceral em Mato Grosso do Sul. Revista da Sociedade Brasileira de Medicina Tropical 39: 446-450.

PASTORINO, ANTÔNIO C; JACOB, CRISTINA M. A.; OSELKA, GABRIEL W. Leishmaniose Visceral: Aspectos Clínicos e laboratoriais. Jornal de Pediatria, Rio de Janeiro, 2002, 1-9p. Disponível em: htt//www.jped.com.br/conteudo/02-78-02120/port_print.htm. 13/06/2008.

QUEIROZ, MÁRCIA J.A.; ALVES, JOÃO G.B.; CORREIA, JAILSON B. Leishmaniose Visceral: Características clinico-epidemiológicas em crianças de área endêmica. Jornal de Pediatria, Rio de Janeiro, 2004, 1-9p. Disponível em:

http//www.jped.com.br/conteudo/04-80-02-141/ port_print.htm.13/06/2008.

REBELO, JM. Frequência horária e sazonalidade de Lutzomia longipalpis (Diptera: Psychodidae: Phlebotominae ) na ilha de São Luís, Maranhão, Brasil. Caderno de Saúde Publica, Rio de Janeiro, p.221-227, jan-fev,2001.

REICHE EM, INOUYE MM, BONAMETTI AM, JANKEVICIUS JV. Doença de Chagas congênita: epidemiologia, diagnóstico laboratorial, prognóstico e tratamento. Jornal de Pediatria 72:125-132, 2006.

REIS, LC; BRITO, MEF; SOUZA, MA; PEREIRA,VRA. Mecanismos Imunológicos na Resposta Celular e Humoral na Leishmaniose Tegumentar \Americana. Rev. Patologia Tropical 2006;35 (2):103-115.

REY, LC; MARTINS, CV; RIBEIRO, HB; LIMA, AAM. American visceral leishmaniasis (kala-azar) in hospitalized children from an endemic area. J Pediatr (Rio J ) 2005; 81:73-84

REY, LUIS. O Complexo "Leishmania donovani” e a Leishmaniose Visceral. In. --Parasitologia. 3. ed. Rio de Janeiro: Guanabara Koogan, 2001. Cap.19, p. 253-265.

RIBEIRO, VM; MICHALICK, MSM. Leishmaniose, Estratégia de Controle. Nosso Clínico, a 4, n 24, p 10, 2001. 
ROMERO, GUSTAVO A. S.; BOELAERT, MARLEEN, (2010). Controlo f visceral leishmaniasis in latim américa - a systematic review. PLoS Negl. Trop. Dis. 2010 january; 4(1):e584.

ROSAS FILHO, MSR; SILVEIRA, FT. Epidemiologia, clínica e imunologia da infecção humana por Leishmania (Leishmania) infantum chagasi em área endêmica de leishmaniose visceral no Pará. Rev Para Med. 2007;31(3):7-18.

SABROZA PC; MARZOCHI, MCA; TOLEDO, LM; MARZOCHI, KB; TRAMONTANO, NC; RANGEL-FILHO, FB. Leishmaniose visceral na cidade do Rio de Janeiro, Brasil. Cadernos de Saúde Pública 1:5-17, 2005.

SANTORO, F.; BOUT, D.; WATTRE, P. \& CAPRON, A., (1976). Imuno-complexos na esquistossomose. I - utilização da fixação do complemento para sua detecção. Rev. Inst. Méd. Trop. São Paulo, 18:152-156.

SCHUBACH, ARMANDO DE OLIVEIRA. Leishmaniose Visceral Americana (Calazar Americano ou Neotropical). In: Parasitologia Humana e Seus Fundamentos Gerais. 2 ed. São Paulo: Atheneu, p 65-80, 2001.

SCODRO, R. B. de L.; Investigation of natural infection by Leishmania in sandflies of Paraná State, Southern Brazil. Curitiba: 2008.

SECRETARIA MUNICIPAL DE SAÚDE. Centro de controle de zoonoses. Manual de Malária, Chagas, Leishmaniose Visceral e Tegumentar para Pessoal de Campo. Araguaína: 2008.

SERAFIM, TD; AFONSO, LCC; REZENDE, SA. Papel da IL-10 na atividade supressora de imunocomplexos ma leishmaniose visceral murina. In: Anais $58^{\circ}$ REUNIÃO ANUAL DA SBPC 2006, Florianópolis.

SENA, JM; ALVES, WA; GOMES, MLSG; ELKHOURY, NSM. Leishmaniose: Situação atual no Brasil. www.saude.gov.br/sinanweb. Acesso em 20/08/2010.

SOUSA, RG; SANTOS, JF; RODRIGUES, HG; AVERSI-FERREIRA, TA. Casos de leishmaniose visceral registrados no município de Montes Claros, Estado de Minas Gerais. Acta Sci Health Sci 2008; 30:155-159.

SOUZA, AL.; NUNES, VLB.; BARRALHO, WV.; ISHIKAWA, EAY. Domestic feline cutaneous leishmaniasis in the municipality of ribas do rio pardo, Mato Grosso do Sul state, Brazil: a case report. 2009. J Venos Anim Toxins incl Trop Dis. V.15. n.2, p.359365 .

SOUZA VMM, JULIÃO FS, NEVES RCS, MAGALHÃES PB, BISINOTTO TV, LIMA AS, OLIVEIRA SS, MOREIRA JR. ED. Ensaio comunitário para avaliação da efetividade de estratégias de prevenção e controle da leishmaniose visceral humana no Município de Feira de Santana, Estado da Bahia, Brasil. Epidemiologia e Serviços de Saúde 2007; 17(2): 97-106. 
TAVARES, W; MARINHO, L.A.C. Rotinas de diagnóstico e tratamento das doenças infecciosas e parasitarias. 1 ed. São Paulo: Atheneu, 2005.1206p.

TONELLO, VM; MISSAWA, NA. Expansão geográfica da leishmaniose visceral no estado de Mato Grosso / Brasil. Secretaria de Estado de Saúde de Mato Grosso (SESMT). Brasil. 2007.

VICKERMAN K, (1974). Ciba Symp, 20(new series):171-89. 